\title{
Ecological and ecotoxicological responses in the assessment of the ecological status of freshwater systems: A case-study of the temporary stream Brejo of Cagarrão (South of Portugal)
}

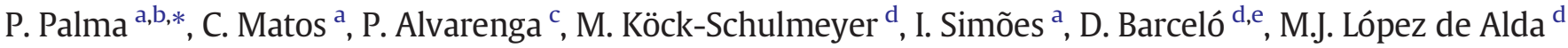 \\ a Departamento de Tecnologias e Ciências Aplicadas; Escola Superior Agrária, Instituto Politécnico de Beja, 7800-295 Beja, Portugal \\ b ICT, Institute of Earth Sciences, University of Évora, Rua Romão Ramalho 59, Évora, Portugal \\ c LEAF, Centro de Investigação em Agronomia, Alimentos, Ambiente e Paisagem, Instituto Superior de Agronomia, Universidade de Lisboa, Tapada da Ajuda, 1349-017 Lisboa, Portugal \\ ' Institute of Environmental Assessment and Water Research (IDAEA), Spanish Council for Scientific Research (CSIC), Jordi Girona 18-26, 08034 Barcelona, Spain \\ e Catalan Institute for Water Research (ICRA), H2O Building, Scientific and Technological Park of the University of Girona, Emili Grahit 101, 17003 Girona, Spain
}

\section{H I G H L I G H T S}

- Multi-metric indices classify the ecological status as reasonable to mediocre.

- Sublethal ecotoxicological endpoints complement the biotic indices.

- Dry phase of the stream occurred very early comparing with previous years.

- Stream with risk to the ecosystem and to public health

- Temporal periods with toxic effects for crustaceans' species and biodiversity compromised.
G R A P H I C A L A B S T R A C T

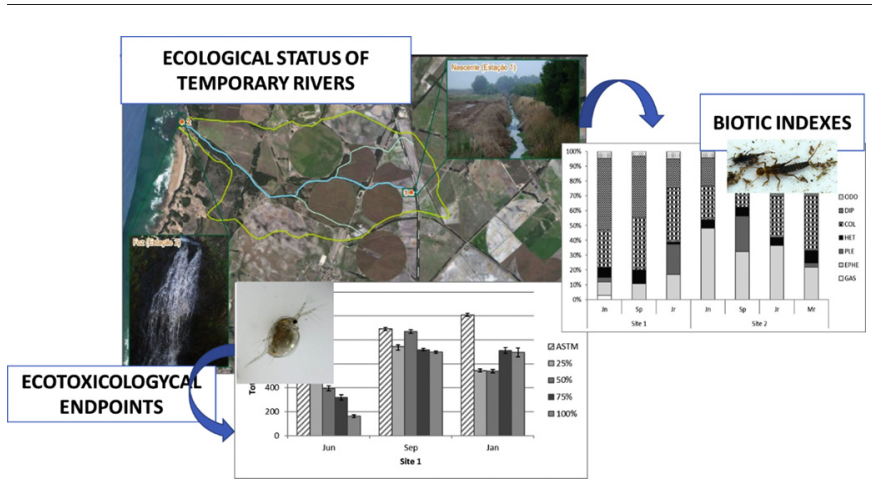

\section{A B S T R A C T}

The objective of the study was to assess the integrated use of macroinvertebrate indexes and ecotoxicological parameters in the evaluation of the ecological status of a temporary stream with a strong agricultural influence. Water quality was analysed at two sampling sites along the stream, considering: chemical supporting parameters; hazardous substances (pesticides); benthic macroinvertebrate communities, through quality (Iberian Biological Monitoring Working Party and Iberian Average Score Per Taxon) and multi-metric indices (Southern Portuguese Index of Invertebrates and Ecological Quality Ratio); and ecotoxicological responses using lethal and sub-lethal bioassays. The water chemical characterization showed high levels of organic matter and nutrients, mainly in the dry period ((biochemical oxygen demand $\left(\mathrm{BOD}_{5}\right): 18.5-25.5 \mathrm{mg} \mathrm{L}^{-1}$, chemical oxygen demand (COD): $60.8-193.7 \mathrm{mg} \mathrm{L}^{-1}$; total phosphorus (TP): $\left.0.17-0.33 \mathrm{mg} \mathrm{L}^{-1}\right)$ ), which may compromise the support of biological life. In accordance with the physicochemical results, the stream had an ecological status less than good. Of the 25 pesticides analysed, only five, namely terbuthylazine, 2-methyl-chlorophenoxyacetic acid, bentazone, mecoprop and metolachlor were quantified. In general, the concentrations of pesticides detected were low, except at the source of the stream in January 2012 (sum of pesticides $2.29 \mu \mathrm{L}^{-1}$ ), mainly due to the concentration of bentazone $\left(1.77 \mu \mathrm{g} \mathrm{L}^{-1}\right)$, both values surpassing the European Commission threshold values. The analysis of benthic macroinvertebrates showed low levels of abundance and family diversity, with communities dominated by resistant groups to organic pollution and pesticides, such as the Chironomidae family. In

\footnotetext{
* Corresponding author at: Department of Applied Sciences and Technologies, Escola Superior Agrária - Instituto Politécnico de Beja, Rua Pedro Soares S/N, Apartado 6155, 7800-295 Beja, Portugal.

E-mail address: ppalma@ipbeja.pt. (P. Palma).
} 
general, the reproduction ecotoxicological results showed a very marked decrease in the number of juveniles per female. The Spearman correlation identified pesticides, namely $\operatorname{MCPA}(R=-0.89 ; p<0.05)$, as the main responsible for the observed effect. The results showed the linearity and complementarity of the two groups of biological responses, allowing to cover the interactions between the ecosystem's species and the different types of pollutants.

(c) 2018 Elsevier B.V. All rights reserved.

\section{Introduction}

Nowadays, the preservation of the structure and function of freshwater ecosystems is essential to ensure economic, cultural, and recreational benefits for human population (Turner and Daily, 2008), and to guarantee the maintenance of ecological balance with the protection of biodiversity (Poff et al., 1997; Naiman et al., 2008). Nowadays, the global change scenario, which entails with the appearance of new stressors, namely changes of climatic patterns (including drought and temperature increase) or of economic, social, and demographic stressors, may influence negatively the quality of freshwater systems incrementing its scarcity and degradability (Stevenson and Sabater, 2010). All these new stressors and deviations impose new challenges for water management, which remain one of the keys for the next decades (Schinegger et al., 2012). Consequently, the implementation of appropriate management actions for each type of freshwater ecosystem ((wetlands, permanent rivers, temporary rivers and streams, and heavily modified waters bodies (HMWB)) requires periodic reviews of water policies and of monitoring programs (Araújo et al., 2014). Moreover, at present, some of these groups of freshwater ecosystems, namely, temporary waters, remain among the least studied freshwater systems worldwide (Acuña et al., 2014), with no parameters and standard values for the good chemical and ecological status. In fact, the Water Framework Directive (WFD) does not integrate assessment parameters for European Mediterranean (EU-Med) temporary waters (systems that are normally dry, at least during a part of the year; Gallart et al., 2016), since many of them are very small (lower than the stated threshold size of 50 ha; Van den Broeck et al., 2015; Nikolaidis et al., 2013). Despite this reality, temporary freshwater systems represent an important role in the Mediterranean region, once they constitute the most dynamic, complex and diverse systems concerning: (a) the hydrological regime (perennial, intermittent which dry to a series of disconnected pools, or ephemeral, which dry completely; Bonada et al., 2007; Gallart et al., 2012); (b) the chemical characteristics, with great variability in the structural parameters and hazardous substances concentrations (Arenas-Sánchez et al., 2016; Petrovic et al., 2011); and (c) the biodiversity, housing both general opportunistic species, as well as temporary ponds species, which are extremely rare, with unknown mechanisms of resistance to extreme conditions (Cottarelli et al., 2010; Acuña et al., 2014; Van den Broeck et al., 2015). Moreover, under climate-change conditions, temporary freshwater systems probably may represent, the most dominant surface-water bodies of the Mediterranean region (Skoulikidis et al., 2017), giving them a major importance as source of water for local people and their livestock and agricultural activities, and, because of that, providing valuable ecosystem services including wildlife habitat, nutrient flux to adjacent ecosystems, flood control, water filtration, and cultural services (Calhoun et al., 2017).

To manage this kind of water body appropriately, incrementing its quality and avoiding the strong decrease of biodiversity observed, it is essential to understand its one dynamic, and determine, if possible, whose parameters (chemical and/or biological) are most sensitive to the pollutants detected in this type of scenario.

Presently, the ecological status of rivers/streams is determined by the assessment of ecological indices, which translate the biodiversity of the system. Relatively to temporary rivers, the structure and composition of the biological communities are adapted to the temporariness of hydrological regime, which induces a high heterogeneity at the system, hindering the definition of reference conditions, as well as the use of indicator species for defining the ecological status (Sánchez-Montoya et al., 2009). These facts highlight that the current classification, based in multi-metric indices, may not be sufficient to interpret the hydrological and biological variability present in the temporary rivers (Munné and Prat, 2009). In addition to this scenario, we cannot forget that, despite the biotic indices are relatively easy to apply, they do not identify causes of impairment, neither subtle effects at the individual level (Damásio et al., 2007; Muñoz et al., 2012), and, hence, when the detection of detrimental effects occur at the community level, it may be too late to recover the ecosystem (Clements and Rohr, 2009).

Many researchers think that the best option to assess the ecological status of water bodies is the use of a tool-box that adds multi-metric indices and ecotoxicological endpoints, especially in aquatic systems that present low biodiversity, such as temporary Mediterranean rivers (Colin et al., 2016; Reyjol et al., 2014; Palma et al., 2016; Van den Broeck et al., 2015; Skoulikidis et al., 2017). This type of strategy will allow a better understanding of the ecosystem functions and dynamics, filling the fragilities of each approach and the gaps between the results from laboratory experiments and field observations (Artigas et al., 2012; Beketov and Liess, 2012).

Considering all these facts, the aim of this study was to evaluate the effectiveness of the use of biological responses, integrating biotic indices and ecotoxicological endpoints, in the detection of pollution induced by agricultural activities in a temporary stream, Brejo of Cagarrão, located in the Mira River Basin, in the South of Portugal.

The selection of Brejo of Cagarrão as a case study was based on the following criteria: (i) it is a southern stream with a temporary hydrological regime; (ii) there is no water quality data for this watercourse; (iii) there are environmental and public health concerns associated with this stream, as it drains directly to Brejo Largo beach; (iv) some local fisherman reported the decrease of the communities of clams and mussels; and (v) it is a watercourse integrated in the Southwest Alentejo and Vicentine Coast Natural Park, a protected region due to its great biodiversity and coastal habitats (Decreto Regulamentar n. $\left.{ }^{\circ} 26 / 95,1995\right)$.

Furthermore, this initial study is integrated in a research line about the quality, function and dynamic of temporary rivers/streams in Mediterranean areas, that intends to deliver a tool-box, which can be used for responding to the main alterations that influence the ecological status of temporary water streams. This action can be useful to support the risk management strategies of this type of systems, to minimize human influences and ensure ecosystem integrity and human safety.

\section{Materials and methods}

\subsection{Study area}

Brejo of Cagarrão is a temporary stream inserted in the Coastal Hydrographic Basin of Mira (Alentejo coast, South of Portugal). According to the Portuguese Water Institute (INAG) (2009), Brejo of Cagarrão is classified as a small river of the South of Portugal $\left(\leq 100 \mathrm{~km}^{2}\right)$, which flows into the Atlantic Ocean, at the Brejo Largo Beach.

The Mira Basin presents a drainage area of $1576 \mathrm{~km}^{2}$, with a lithology mainly constituted by schist, greywacke, and sandstones (85\%), sands, little consolidated sandstones and clays (9\%), and a slight percentage of metavolcanics (4\%) (Mil-Homens et al., 2014). 
The climate of the Alentejo coast is Mediterranean, with a strong maritime influence, inducing mild temperatures throughout the year (ranging from 10 to $21^{\circ} \mathrm{C}$ ) (ARHAlentejo, 2012). During the study period, the clime was characterized by an average atmospheric temperature of $14.5^{\circ} \mathrm{C}$, ranging from $8{ }^{\circ} \mathrm{C}$ in January to $21^{\circ} \mathrm{C}$ in August (www.snirh.pt, $2010 / 2011 ; 2011 / 2012$ ). The average monthly precipitation for the hydrologic year of 2009/2010 was $53.4 \mathrm{~mm}$ (www.snirh.pt, 2008/2009), and for 2010/2011 it was $70.3 \mathrm{~mm}$ (www.snirh.pt, 2010/2011), and for the hydrologic year of 2011/2012 it was $29.4 \mathrm{~mm}$ (www.snirh.pt, 2011/ 2012). So, the values of precipitation for the hydrologic year of 2011/ 2012 were extremely low, comparing with the years before, highlighting the exceptional circumstance of no precipitation in February 2012.

In the riparian vegetation, along the water margins and banks, some degraded communities are evident, probably due to the frequent interventions related to the intense agricultural and livestock activity in the surrounding area. The gallery is practically non-existent and dominated by exotic species, mainly Acacia sp., Arundo donax, Datura stramonium, as well as by some opportunistic species, like Rubus ulmifolius and Dittrichia viscosa subs Revoluta (ARHAlentejo, 2012).

The main activity along the basin is the agriculture, representing about $52 \%$ of the catchment surrounding area; the main crop is maize, with an area of production of about $21 \%$. Presently the main pressures around the basin are agriculture, aquaculture, mining activity and domestic effluents from the municipalities of Odemira, Zambujeira and Vila Nova de Milfontes (Medeiros et al., 2012).

Two sampling sites were established at Brejo of Cagarrão for the characterization of the water quality status during a period of time of 9 months: site 1, located at the source of Brejo of Cagarrão watercourse (N 37 $40^{\prime} 19.90^{\prime \prime} ;$ W 8 $8^{\circ} 45^{\prime} 37.09^{\prime \prime}$ ); and site 2, located at the mouth of

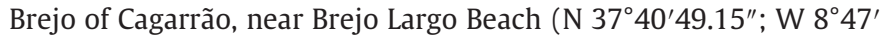
$44.48^{\prime \prime}$ ), with a distance of $4.5 \mathrm{~km}$ between sampling sites (see Fig. 1).

\subsection{Sampling}

Sampling was carried out during the hydrological years of 2010/ 2011 and 2011/2012, from June 2011 to March 2012. Water and macroinvertebrates were collected on June and September of 2011, and on January and March of 2012. The wet season included the months of January (Jr) and March (Mr) and the dry season included the months of June (Jn) and September (Sp); these periods were defined by the Portuguese Environmental Protection Agency (APA), for the Alentejo region (ARHAlentejo, 2011).

Considering the macroinvertebrates, the INAG sampling protocol for temporary rivers (2008) indicates that the sampling must occur at spring, under continuous flow conditions, when community and habitat diversity are generally considered at a maximum. Despite that, in the present study the macroinvertebrates were sampled during the whole period of the study, to try to correlate the temporal and spatial chemical variability observed in the water with the biotic indices and ecotoxicological endpoints obtained. However, during this study, the dry phase of the stream occurred in March, which is considered the beginning of the spring, making impossible the sampling in this month at the source of the stream.

Sampling collection at each site included: (i) $1 \mathrm{~L}$ of surface water on polyethylene (PET) bottles for the analysis of physicochemical support parameters; (ii) 1 L of surface water on amber low-density polyethylene (LDPE) bottles for the analysis of pesticides; (iii) $5 \mathrm{~L}$ on PET bottles for ecotoxicological assays. All the samples were collected on the shore, at a depth of $50 \mathrm{~cm}$ (when possible) and transported to the laboratory in coolers at $4{ }^{\circ} \mathrm{C}$, where they were preserved and stored, following the requisites for water conservation for each parameter, until the analysis was performed (maximum storage time: 1 week) (APHA, 1998). The bottles for the analysis of pesticides were stored in the dark at $-18{ }^{\circ} \mathrm{C}$ until analysis. For the water ecotoxicological assays, samples were previously filtered through $0.45 \mu \mathrm{m}$ membrane filters and stored at $-20^{\circ} \mathrm{C}$.

Temperature, $\mathrm{pH}$, dissolved oxygen, and electrical conductivity were measured in situ, using a multiparametric probe YSI 6820 MPS probe ${ }^{\circ}$.

\subsection{Physicochemical analyses}

\subsubsection{Water characterization}

Water chemical parameters were determined using officially recommended methods of analysis (APHA, 1998), which are displayed in

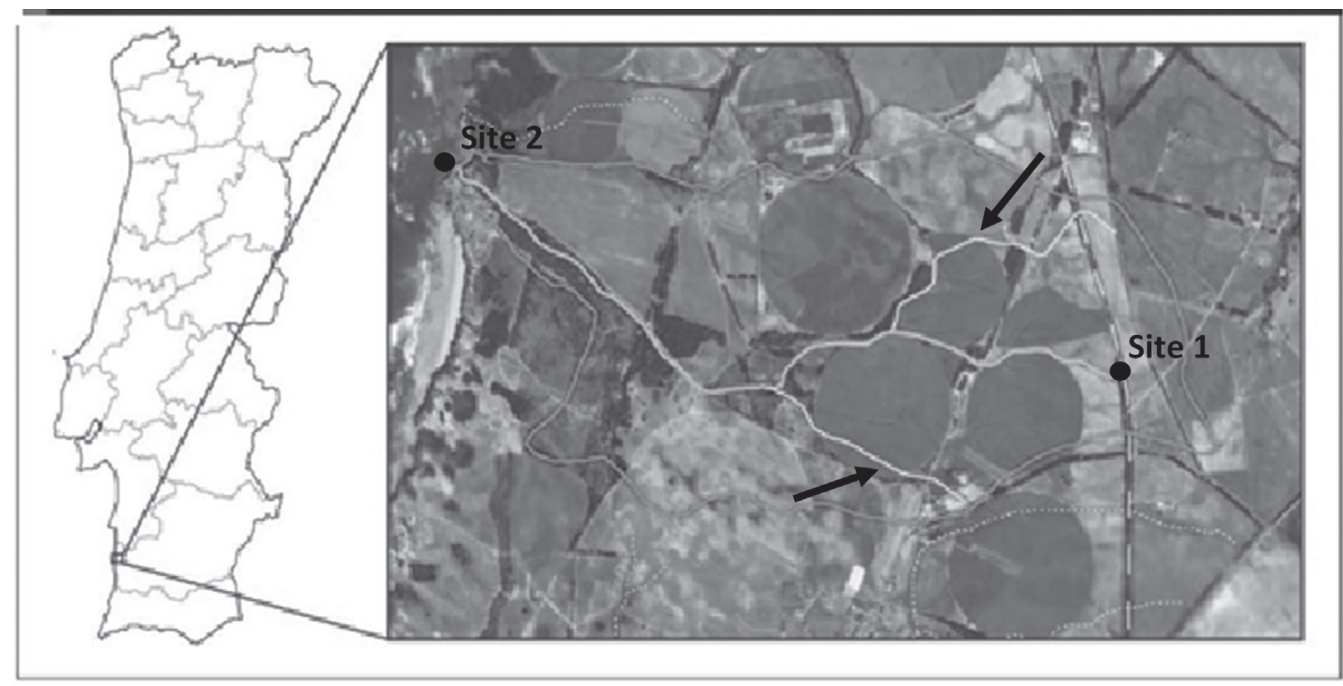

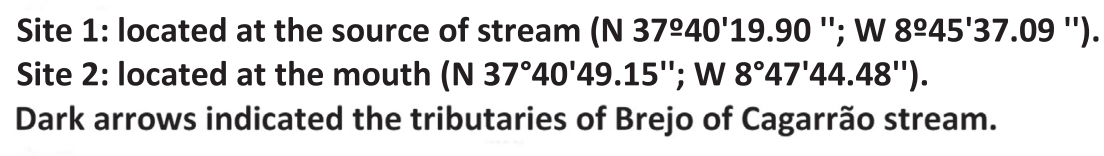

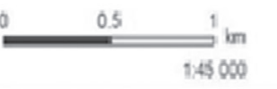

Fig. 1. Map showing the two sampling points at Brejo Cagarrão located at Mira Basin, in the South of Portugal. 
Table 1, along with their units, the analytical techniques employed and the respective maximum concentrations, considering the normative of INAG (2009), adapted by the Water Framework Directive (WFD) (ECC, 2000) and the Decreto-Lei $n^{\circ} .236 / 98$. The selection of the chemical parameters was done bearing in mind the support parameters that must be evaluated for the characterization of the ecological status of rivers (INAG, 2009). Trace elements quantification included $\mathrm{Cd}, \mathrm{Pb}, \mathrm{Cu}, \mathrm{Zn}$, As, Fe, and Mn. However, only As, Fe, and Mn presented temporal and spatial variability in surface water, surpassing the stipulated limit values of the Portuguese Legislation (Decreto-Lei $n^{\circ}$. 236/98), which justified their analysis in the study.

\subsubsection{Pesticides analysis}

A total of 25 target pesticides, representative of different chemical classes and modes of action (herbicides, insecticides and fungicides), were selected to be analysed, considering those included in the list of priority substances from the European Union's water policies (Directive 200/ $60 / \mathrm{EC}$ ), the extent of their use, and the suitability of their analysis by means of liquid chromatography-tandem mass spectrometry. This list of compounds comprised triazines ((atrazine, cyanazine, simazine, terbuthylazine and the degradation products deisopropylatrazine (DIA) and desethylatrazine (DEA)), phenylureas (chlortoluron, diuron, isoproturon and linuron), chloroacetanilides (alachlor and metolachlor), anilides (propanil), organophosphorous compounds (diazinon, dimethoate, chlorfenvinphos (CFP), malathion, fenitrothion, and the metabolites fenitrothion oxon ((FOX) and malaoxon (MOX)), thiocarbamates (molinate), and acid compounds ((2,4-dichlorophenoxy) acetic acid (2,4-D), bentazone, (4-chloro-2-methylphenoxy) acetic acid (MCPA) and mecoprop)).

Target analysis of these compounds in water was performed with a fully automated method based on on-line solid phase extraction-liquid chromatography-electrospray-tandem mass spectrometry (SPE-LCESI-MS/MS), after previous filtration of the samples and addition of the surrogate standards, as described in Palma et al. (2014a). The analyses were performed with a Prospekt-2 system (Spark Holland, Emmen, The Netherlands) connected in series with a binary HPLC pump Model 1525 and a TQD triple-quadrupole mass spectrometer, both from Waters ((Milford, MA, USA). On-line SPE of the samples $(5 \mathrm{~mL})$ was carried out in duplicate using two different disposable polymeric cartridges (Hysphere Resin GP and PLRP-s, both from Spark Holland). LC separation was achieved in a Purospher STAR-RP-18e column $(125 \times 2 \mathrm{~mm}$, $5 \mu \mathrm{m}$ ) from Merck (Darmstadt, Germany). ESI-MS/MS detection was performed in both positive and negative ionization modes and acquisition under selected reaction monitoring (SRM) conditions recording 2 SRMs per analyte and 1 SRM per surrogate standard. A total of 22 isotopically-labelled compounds were added to the samples for quantification by the isotope dilution method. Limits of detection achieved with this methodology were within 0.03 and $5.2 \mathrm{ng} \mathrm{L}^{-1}$, except in the case of deisoprylatrazine $\left(35 \mathrm{ng} \mathrm{L}^{-1}\right)$, while limits of quantification were below $10 \mathrm{ng} \mathrm{L}^{-1}$ in all cases but bentazone $\left(12 \mathrm{ng} \mathrm{L}^{-1}\right)$, fenitrothion (17 $\mathrm{ng} \mathrm{L}^{-1}$ ) and deisoprylatrazine (116 ng L ${ }^{-1}$ ). Further details on the experimental conditions and performance of the method can be found in Palma et al. (2014a).

\subsection{Ecotoxicological endpoints}

The test battery was outlined to integrate assays assessing lethal and sub-lethal responses with representative species of key taxonomic and functional groups. All bioassays performed have largely been used in other ecotoxicological studies and most of them have already been standardized: (i) lethal endpoints were investigated using two crustaceans with different sensitivities, namely, Daphnia magna and Thamnocephalus platyurus; (ii) bioassays with sublethal endpoints included luminescence inhibition of Vibrio fischeri and reproduction assay with Daphnia magna. Temperature, pH, dissolved oxygen (DO) and electric conductivity (EC) of the samples were measured and were in accordance with the standard protocols used. A reference test with potassium dichromate $\left(\mathrm{K}_{2} \mathrm{Cr}_{2} \mathrm{O}_{7}\right)$ was conducted as a positive control. The lethal assays were used for assessing drastic conditions relative to pollution processes while sublethal bioassays, namely those that integrate the whole life-cycle of the organism, have a great ecological relevance.

\subsubsection{V. fischeri bioassay (Luminotox®)}

Luminotox ${ }^{\circledR}$ was used to evaluate the inhibition of the marine bacteria $V$. fischeri luminescence (NRRL B-11177), according to the protocol "DR LANGE luminescent bacteria test" following ISO 11348-2 (1998). The bacteria were supplied as liquid-dried solution, by Dr. Lange GmbH \& Co. KG, Düsseldorf, Germany. Tests were carried out using the following dilutions $(100,50,25,12.5,6.25$ and $3.125 \%, v / v)$. Two replicates per treatment were used. The inhibition of the bacteria natural light emission was measured against a non-toxic control $(2 \% \mathrm{NaCl}$ solution), at a temperature of $15 \pm 0.5^{\circ} \mathrm{C}$. For each sample, bioluminescence was measured before and after the desired incubation period ( $30 \mathrm{~min}$ ) and $\mathrm{EC}_{50}$ (\%; the concentration of each sample that reduced $50 \%$ of the bacterial luminescence) was determined.

\subsubsection{T. platyurus bioassay}

The effect of the samples (water and pore-water) on the mortality of T. platyurus was evaluated in accordance with the standard operational procedure provided in the THAMNOTOXKIT FTM kit (Persoone, 1999). The concentrations tested were $25,50,75$, and $100 \%(v / v)$, using the sample or its dilution with synthetic freshwater (included in the test

Table 1

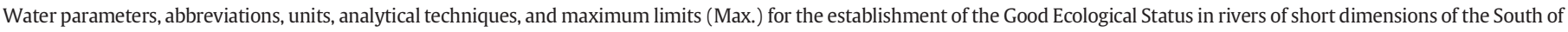
Portugal, adapted from Water Framework Directive (ECC, 2000; INAG, 2009).

\begin{tabular}{|c|c|c|c|c|c|}
\hline Parameter & Abbreviation & Units & Analytical technique & Detection limit & Max. \\
\hline Temperature & $\mathrm{T}$ & ${ }^{\circ} \mathrm{C}$ & Temperature probe & & - \\
\hline $\mathrm{pH}$ & $\mathrm{pH}$ & Sorensen scale & Potentiometry $/ \mathrm{pH}$ probe & & $6-9$ \\
\hline Dissolved oxygen & DO & $\%$ & Oxygen probe & & $60-120$ \\
\hline Electrical conductivity & EC & $\mu \mathrm{S} \mathrm{cm}-1$ & Conductometry & & - \\
\hline Chemical oxygen demand & COD & $\mathrm{mg} \mathrm{L}^{-1}$ & Dichromate technique & 1.7 & - \\
\hline Biochemical oxygen demand & $\mathrm{BOD}_{5}$ & $\mathrm{mg} \mathrm{L}^{-1}$ & Respirometric & 1 & $\leq 6 \mathrm{mg} \mathrm{O}_{2} \mathrm{~L}^{-1}$ \\
\hline Nitrite & $\mathrm{NO}_{2}-\mathrm{N}$ & $\mathrm{mg} \mathrm{L}^{-1}$ & MAS & 0.01 & - \\
\hline Nitrate & $\mathrm{NO}_{3}-\mathrm{N}$ & $\mathrm{mg} \mathrm{L}^{-1}$ & MAS & 0.04 & $\leq 25 \mathrm{mg} \mathrm{NO}_{3}-\mathrm{N} \mathrm{L}^{-1}$ \\
\hline Total nitrogen & TN & $\mathrm{mg} \mathrm{L}^{-1}$ & MAS & 0.0003 & - \\
\hline Ammonium & $\mathrm{NH}_{4}-\mathrm{N}$ & $\mathrm{mg} \mathrm{L}^{-1}$ & MAS & 0.01 & $\leq 1 \mathrm{mg} \mathrm{NH}_{4}-\mathrm{N} \mathrm{L}^{-1}$ \\
\hline Total phosphorus & $\mathrm{TP}$ & $\mathrm{mg} \mathrm{L}^{-1}$ & MAS & 0.003 & $\leq 0.13 \mathrm{mg} \mathrm{TP} \mathrm{L}^{-1}$ \\
\hline Chloride & $\mathrm{Cl}$ & $\mathrm{mg} \mathrm{L}^{-1}$ & MAS & 4 & $200^{(a)}$ \\
\hline Iron & $\mathrm{Fe}$ & $\mathrm{mg} \mathrm{L}^{-1}$ & FAAS & 0.013 & $0.30^{(a)}$ \\
\hline Manganese & Mn & $\mathrm{mg} \mathrm{L}^{-1}$ & FAAS & 0.001 & - \\
\hline Arsenic & As & $\mathrm{mg} \mathrm{L}^{-1}$ & ETAAS & 0.0012 & $0.05^{(a)}$ \\
\hline
\end{tabular}

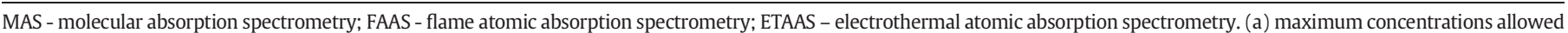
by Portuguese legislation concerning the water quality for multiple uses, such as treatment for human consumption (Law-Decree No. 236/98). 
kit, also used as a non-toxic control). Larvae of shrimp T. platyurus ( $<24 \mathrm{~h}$ ), obtained by the hatching of cysts, were incubated in 24-well plates, with $1.0 \mathrm{~mL}$ of test solution and ten crustaceans per well, using four replicates per treatment, at $25{ }^{\circ} \mathrm{C}$ for $24 \mathrm{~h}$ in the dark. Animals were not fed during the test. The number of dead shrimps after 24-h contact with each test solution was used as the selected endpoint, and the $\mathrm{EC}_{50}(\%)$ was calculated.

\subsubsection{D. magna bioassays}

Daphnids were obtained from continuous cultures maintained in the laboratory in a medium of American Society for Testing and Materials (ASTM) hard water (with a density of 15 individuals per $800 \mathrm{~mL}$; ASTM, 1998) at $20 \pm 1{ }^{\circ} \mathrm{C}$ and with a $16 \mathrm{~h}$ light: $8 \mathrm{~h}$ dark photoperiod. Daphnids were fed with algae (Pseudokirchneriella subcapitata) with a density of $3.0 \times 10^{5}$ cells $\mathrm{mL}^{-1}$ daphnia $^{-1}$ (an equivalent carbon content of $2.65 \mathrm{mg} \mathrm{C} / \mathrm{mL}$ ) and organic additive Marinure "25" (Pann Britannica Industries Ltd., Waltham Abbey, UK), an extract from the algae Ascophyllum nodosum (Baird et al., 1989), at a concentration of $4.0 \mathrm{~mL} \mathrm{~L}^{-1}$.

The D. magna acute bioassay was performed according to the ISO 6341 (1996) guideline. For each treatment, 20 juveniles $(<24 \mathrm{~h})$ between the third and the fifth brood were used. The water samples were diluted with ASTM solution $(12.5,25,50,75$ and $100 \% \mathrm{v} / \mathrm{v})$. All assays had a negative control with ASTM. Animals were not fed during the test. After $48 \mathrm{~h}$, daphnids were observed for their mobility/death and the $\mathrm{EC}_{50}(\% v / \mathrm{v})$ was determined.

To assess the effects of water samples on the reproduction of daphnids, tests were conducted in accordance with the OCDE D. magna reproduction test (OCDE, 1998). $<24$ h old neonates from the third-brood were exposed to the different dilutions of water samples $(25 \%, 50 \%, 75 \%$, and $100 \% \mathrm{v} / \mathrm{v})$ and to the control medium ASTM. Ten replicates per treatment group were used with one daphnid per glass jar, filled with $50 \mathrm{~mL}$ of test solution. Test solutions were renewed three times a week and at the same time the organisms were fed with

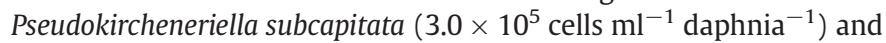
Marinure extract ${ }^{\circledR}$. These maintenance procedures were like those for the stock cultures. All experiments were conducted for $21 \mathrm{~d}$, in a chamber with a constant temperature, $20 \pm 1{ }^{\circ} \mathrm{C}$, and a photoperiod of $16 \mathrm{~h}$ light and $8 \mathrm{~h}$ dark. During the assay the number of living offspring produced per female was recorded for each broad. After the 21d exposure period, the total number of viable offspring produced by each female was used to estimate the reproduction rate.

\subsection{Benthic macroinvertebrates communities}

Benthic macroinvertebrates were collected following the proportional habitat sampling protocol (PHS), a multi-habitat procedure based on the collection of six samples of $1 \mathrm{~m}$ drag, distributed proportionally by the different types of habitat (gravel, rocks, pebbles, sands, organic materials, aquatic macrophytes) (INAG, 2008). The 50-m-long sampling area was selected to cover the greatest possible diversity of microhabitats, representing $25 \mathrm{~m}$ upstream and $25 \mathrm{~m}$ downstream of an area of turbulent flow (INAG, 2008). The sampling was performed with a hand net of $25 \times 25 \mathrm{~cm}$ and a mesh size of $0.5 \mathrm{~mm}$. The hand net method implies that the operator needs to place the net against the current and agitate the substrate to a depth of ca. $10 \mathrm{~cm}$ to dislodge the macroinvertebrates to the water column, which are dragged into the network ("kick sampling"). Samples were preserved in situ with $4 \%(v / v)$ of formaldehyde and transported to the laboratory. Prior to the identification of taxonomic level, the organisms were preserved in $70 \%$ ethanol. The organisms were identified under a microscope of 40× magnification (Leica ${ }^{\circledR}$ ).

In the present study, the biotic endpoints were selected to allow the analysis of the variability and abundance of macroinvertebrate communities at the ecosystem, namely: single metrics: (i) macroinvertebrate abundance (S); (ii) Shannon-Wiener index (H); (iii) Evenness index
(E); (iv) percentage of Ephemeroptera, Plecoptera and Trichoptera (\% EPT); and quality indices: (i) Iberian Biological Monitoring Working Party (IBMWP; Alba-Tercedor and Sánchez-Ortega, 1988); (ii) Iberian Average Score Per Taxon (IASPT; Alba-Tercedor and Sánchez-Ortega, 1988); (iii) multi-metric Southern Portuguese Index of Invertebrates (IPtIs); and (iv) Ecological Quality Ratio (EQR) that, according to the intercalibration exercise of the geographic Mediterranean group, should be used to evaluate the ecological state of Portuguese southern rivers based on the macroinvertebrates communities (INAG, 2009).

\subsection{Statistics}

Water quality data were subjected to descriptive statistics (mean and standard deviation), and the spatial and seasonal variations of the parameters were analysed.

To assess possible associations among variables, a correlation test was performed. Considering the number of samples, and that most data failed the Shapiro-Wilk normality test, correlations between parameters were assessed using the Spearman's rank coefficients, as a non-parametric measure of the correlation between the variables, which is computed over ranked data (Wunderlin et al., 2001). With the Spearman correlations, we intended to determine whether two variables are associated or not, the direction of the association, and whether the association is strong or weak. Furthermore, as we had chemical and biological parameters to correlate, data were normalized to avoid misclassification due to the wide differences in data dimensionality.

The estimation of the single metrics and the quality indices were performed following the equations displayed in Table 2 . The IPtIs values were obtained from the sum of the weighted metrics, which were calculated multiplying the normalized value of the metric (obtained by the quotient between the value calculated for each metric and the corresponding reference value, see Table 2 ) by the respective weighting factor. The Ecological Quality Ratio (EQR) was obtained dividing the IPtIs value by the $\mathrm{IPtI}_{\mathrm{S}}$ reference value of 0.99 for small southern rivers (INAG, 2009).

For the ecotoxicological endpoints, the $\mathrm{EC}_{50}(\%)$ for the $V$. fischeri bioluminescence inhibition values were determined using LUMISsoft 4

Table 2

Biotic indices and reference values used to assess the ecological status of Brejo Cagarrão (South of Portugal).

\begin{tabular}{|c|c|c|}
\hline & Equation & $\begin{array}{l}\text { Reference } \\
\text { value }\end{array}$ \\
\hline \multicolumn{3}{|l|}{ Single metric } \\
\hline Abundance $(S)$ & & 27.00 \\
\hline $\begin{array}{l}\text { Ephemera, Plecoptera, } \\
\text { Trichoptera Index (EPT) } \\
(\%)\end{array}$ & $\mathrm{EPT}=\left(\Sigma\left(S_{\mathrm{EPT}}\right) / \mathrm{S}\right) * 100$ & 10.00 \\
\hline Evenness index (E) & $\mathrm{E}=\mathrm{H} / \ln S$ & - \\
\hline Shanon Wienner index $(\mathrm{H})$ & $\begin{array}{l}\mathrm{H}=-\Sigma \mathrm{pi} \ln \mathrm{pi} \\
\text { where } \mathrm{pi}=\mathrm{ni} / \mathrm{N}\end{array}$ & - \\
\hline \multicolumn{3}{|l|}{ Quality indices } \\
\hline $\begin{array}{l}\text { Iberian Bio-Monitoring } \\
\text { Working Party index } \\
\text { (IBMWP) }\end{array}$ & $\mathrm{IBMWP}=\Sigma \mathrm{SF}$ & 101 \\
\hline $\begin{array}{l}\text { Iberian Average Score Per } \\
\text { Taxon (IASPT) }\end{array}$ & IASPT-2 = ((IBMWP/S)-2) & 3.29 \\
\hline \multicolumn{3}{|l|}{ Multi-metric index } \\
\hline $\begin{array}{l}\text { Southern Portuguese Index of } \\
\text { Invertebrates }\left(\mathrm{IPtI}_{\mathrm{s}}\right)\end{array}$ & $\begin{array}{l}\mathrm{IPtI}_{\mathrm{S}}=\mathrm{S} * 0.4+\mathrm{EPT} * 0.2+(\mathrm{IASPT}-2) \\
* 0.2+\log \left(\Sigma \mathrm{S}_{\mathrm{EPTCD}}+1\right) * 0.2\end{array}$ & 0.99 \\
\hline
\end{tabular}

Where: $\mathrm{S}_{\mathrm{EPT}}$ : abundance of taxa belonging to the Ephemera, Plecoptera, Trichoptera order; S: number of Taxa; ni: number of individuals of each Taxon; $\mathrm{N}$ : number of total individuals; SF: score factor relatively to the pollution sensitivity of each taxa (1 (more resistant) to 10 (more sensitive)), adapted from Alba-Tercedor and Sánchez-Ortega, 1988); $\mathrm{S}_{\mathrm{EPTCD}}$ abundance of the individuals belonging to the families Chloroperlidae, Nemouridae, Leuctridae, Leptophlebiidae, Ephemerellidae, Philopotamidae, Limnephilidae, Psychomyiidae, Sericostomatidae, Elmidae, Dryopidae, Athericidae. 
Software ${ }^{\mathrm{TM}}$. The $\mathrm{EC}_{50}(\%)$ for the T. platyurus and D. magna mortality data were determined using the probit analysis (Finney, 1971). Data of reproduction and inhibition growth bioassays were checked for homogeneity of variance by the Kolmogorov-Smirnov test (Sokal and Rohlf, 1995 ) and, when possible, subjected to one-way analysis of variance (ANOVA). Data, which do not satisfy the assumption for ANOVA, were analysed non-parametrically using Kruskal-Wallis ANOVA by ranks test. Whenever significant differences were found $(p<0.05)$, a post hoc Dunnett's test was used to compare treatments with the control, for an alpha value of 0.05 as the significant level (Zar, 1996).

The principal components analysis (PCA) was applied with the objective of determining the main environmental parameters (support parameters and hazardous substances) that account for the variability of the water body status/quality and tried to correlate them with the biotic indices and ecotoxicological endpoints applied. Before the application of multivariate statistical analysis, the data were normalized $(\log (x+1)$; $\mathrm{x}=$ mean value) to avoid misclassification due to the wide differences in data dimensionality (Liu et al., 2003; Simeonov et al., 2003). Statistical analyses were carried out with the software Statistica 6.0.

\section{Results and discussion}

\subsection{Physicochemical supporting parameters}

At the present study the dry phase of the stream occurred during the early spring (March 2012). This inflection of the ecosystem hydrological conditions occurred earlier than usual, considering the normal flow patterns observed in temporary rivers/streams in the Mediterranean area (Arenas-Sánchez et al., 2016). Nevertheless, in recent years, in the region of Alentejo (South of Portugal), with a strong influence of the Mediterranean climate, a shortening of the rainy season, with lower precipitation levels, and the corresponding increment of extreme drought periods, has been observed. In fact, in the hydrological year of 2011/2012, during the winter (mainly in December 2011 and January 2012), the rainfall levels were very low, and no precipitation occurred in February 2012 (as already reported; www.snirh.pt, 2011/2012). Hence, these extreme hydrological conditions induced an early cessation of flow in the stream.

At the mouth of the stream, this inflection of the ecosystem did not occur, due to the two tributaries to the Brejo of Cagarrão (see Fig. 1). Thus, in this scenario, and whenever possible, we tried to establish correlations among the chemical dynamics, the biological communities and the ecotoxicological responses, at both stream sampling sites.
The temporal and spatial variability of the most relevant physicochemical parameters that support the biological life of Brejo of Cagarrão is described in Table 3. According to the criteria for the classification of the status of surface water bodies ((INAG, 2009, adapted from WFD (ECC, 2000)), these parameters assess the general status of the watercourse, giving us information about the respective level of oxygenation, state of acidification and nutrients profile.

The results highlight that most of the parameters, except of $\mathrm{pH}$ and electric conductivity (EC), express significant temporal and spatial variations during the study, which may be caused by: (i) the hydrologic regime of the stream; (ii) climatic factors; and (iii) point and/or diffuse pollution sources.

Concerning the parameters determined "in situ" ( $\mathrm{pH}$ and EC), and according to the reference values for small rivers of the South of Portugal (INAG, 2009), Brejo of Cagarrão presented a Good Status at both sampling sites during the study period.

With respect to dissolved oxygen (DO), the results highlight a high temporal and spatial variability of the values obtained. Thus, in the stream source, the DO was always outside the proposed limits for this type of surface water (60-120\%) during the flow phase, achieving lower values in July and September 2011 and higher percentages of saturation in January 2012. At the mouth of the stream (site 2), the DO values remained between the limits for the classification of Good Status, though in March 2012 the DO achieved the highest values (117\%), near the upper limit. In line with the matrix of Spearman's coefficients correlation $(R)$ (see Table S1), DO displayed a negative correlation with the temperature $(R=-0.80 ; p<0.05)$, which indicates that the temperature was the most important physical factor for the natural variability of the DO in the stream. In fact, the winter low temperatures increase the solubility of oxygen, while in the summer, the temperature increase induces a natural decrease of DO levels (Palma et al., 2016). Furthermore, lower concentrations of DO during the summer may also relate to the decomposition of aquatic plants, particularly at the end of the growing season, and with low stream flow conditions. Another important factor, that may contribute to the DO drop down during the summer period, is the addition of oxygen-demanding organic matter to the stream system (e.g. sewage, agricultural runoff, etc.) (Harvey et al., 2011). Regarding what occurred at the source of the stream, the results point to the increment of pollution processes, such as inflows of untreated or inefficiently treated domestic wastewaters, with large amounts of nutrients discharged to the watercourse, as well as, runoff from agricultural activities, which are the priority activities around the basin.

Table 3

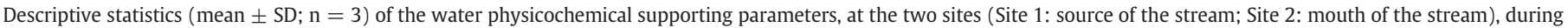
2011-2012.

\begin{tabular}{|c|c|c|c|c|c|c|c|c|}
\hline & \multicolumn{8}{|c|}{ Brejo of Cagarrão } \\
\hline & \multicolumn{4}{|l|}{ Site 1} & \multicolumn{4}{|l|}{ Site 2} \\
\hline & June & September & January & March & June & September & January & March \\
\hline $\mathrm{T}\left({ }^{\circ} \mathrm{C}\right)$ & $21.5 \pm 0.2$ & $23.6 \pm 0.3$ & $9.9 \pm 0.1$ & (a) & $23 \pm 0.5$ & $25.1 \pm 0.2$ & $9.9 \pm 0.1$ & $12.3 \pm 0.1$ \\
\hline $\mathrm{pH}$ & $7.2 \pm 0.6$ & $7.0 \pm 0.3$ & $6.9 \pm 0.5$ & & $7.6 \pm 0.2$ & $6.9 \pm 0.3$ & $7.2 \pm 05$ & $7.7 \pm 0.4$ \\
\hline $\mathrm{EC}\left(\mu \mathrm{sm}^{-1}\right)$ & $743 \pm 53$ & $890 \pm 48$ & $625 \pm 27$ & & $727 \pm 38$ & $739 \pm 45$ & $666 \pm 32$ & $599 \pm 51$ \\
\hline $\mathrm{DO}(\%)$ & $53 \pm 0.8$ & $52 \pm 1.0$ & $125 \pm 1.0$ & & $60 \pm 0.6$ & $88 \pm 0.9$ & $98 \pm 1.0$ & $117 \pm 1.1$ \\
\hline $\mathrm{BOD}_{5}\left(\mathrm{mg} \mathrm{L}^{-1}\right)$ & $25.50 \pm 0.71$ & $18.50 \pm 0.71$ & $25.50 \pm 0.71$ & & $7.50 \pm 2.12$ & $10.50 \pm 0.71$ & $4.0 \pm 1.41$ & $<\mathrm{LD}$ \\
\hline $\operatorname{COD}\left(\mathrm{mg} \mathrm{L}^{-1}\right)$ & $60.80 \pm 2.77$ & $61.23 \pm 5.17$ & $193.67 \pm 2.89$ & & $38.40 \pm 0.51$ & $35.71 \pm 4.76$ & $67.33 \pm 2.31$ & $29.90 \pm 3.25$ \\
\hline $\mathrm{TN}\left(\mathrm{mg} \mathrm{L}^{-1}\right)$ & $37.75 \pm 7.27$ & $0.86 \pm 0.06$ & $3.27 \pm 0.27$ & & $0.68 \pm 0.20$ & $1.16 \pm 0.29$ & $0.72 \pm 0.24$ & $0.38 \pm 0.03$ \\
\hline $\mathrm{NH}_{4}-\mathrm{N}\left(\mathrm{mg} \mathrm{L}^{-1}\right)$ & $29.03 \pm 0.13$ & $0.06 \pm 0.003$ & $0.59 \pm 0.01$ & & $0.22 \pm 0.01$ & $0.87 \pm 0.001$ & $0.061 \pm 0.003$ & $0.03 \pm 0.005$ \\
\hline $\mathrm{NO}_{3}-\mathrm{N}\left(\mathrm{mg} \mathrm{L}^{-1}\right)$ & $25.22 \pm 0.89$ & $17.04 \pm 0.26$ & $4.93 \pm 0.37$ & & $7.08 \pm 0.18$ & $8.96 \pm 0.16$ & $18.67 \pm 0.65$ & $2.4 \pm 0.03$ \\
\hline $\mathrm{NO}_{2}-\mathrm{N}\left(\mathrm{mg} \mathrm{L}^{-1}\right)$ & $1.18 \pm 0.10$ & $0.33 \pm 0.012$ & $0.26 \pm 0.005$ & & $0.09 \pm 0.010$ & $1.04 \pm 0.04$ & $0.12 \pm 0.001$ & $0.02 \pm 0.002$ \\
\hline $\mathrm{TP}\left(\mathrm{mg} \mathrm{L}^{-1}\right)$ & $0.23 \pm 0.001$ & $0.17 \pm 0.004$ & $0.33 \pm 0.005$ & & $0.06 \pm 0.002$ & $0.15 \pm 0.01$ & $0.32 \pm 0.03$ & $0.006 \pm 0.0001$ \\
\hline $\mathrm{Cl}\left(\mathrm{mg} \mathrm{L}^{-1}\right)$ & $128.7 \pm 1.11$ & $109.6 \pm 3.99$ & $168.2 \pm 7.39$ & & $130.4 \pm 3.99$ & $125.8 \pm 1.99$ & $146.9 \pm 2.05$ & $143.0 \pm 1.93$ \\
\hline $\mathrm{Fe}\left(\mathrm{mg} \mathrm{L}^{-1}\right)$ & $0.56 \pm 0.05$ & $0.46 \pm 0.02$ & $1.99 \pm 0.03$ & & $0.59 \pm 0.01$ & $0.77 \pm 0.01$ & $0.72 \pm 0.02$ & $0.29 \pm 0.01$ \\
\hline $\operatorname{Mn}\left(\mathrm{mg} \mathrm{L}^{-1}\right)$ & $0.25 \pm 0.01$ & $0.03 \pm 0.01$ & $0.16 \pm 0.02$ & & $0.14 \pm 0.01$ & $0.21 \pm 0.06$ & $0.02 \pm 0.01$ & $0.01 \pm 0.001$ \\
\hline As $\left(\mathrm{mg} \mathrm{L}^{-1}\right)$ & $0.008 \pm 0.001$ & $0.002 \pm 0.0001$ & $0.007 \pm 0.001$ & & $0.003 \pm 0.001$ & $0.002 \pm 0.001$ & $0.002 \pm 0.001$ & $0.001 \pm 0.001$ \\
\hline
\end{tabular}

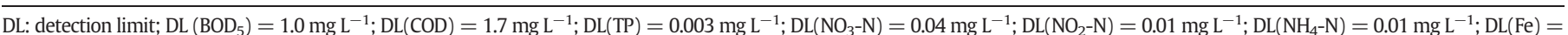
$0.013 \mathrm{mg} \mathrm{L}^{-1} ; \mathrm{DL}(\mathrm{Mn})=0.001 \mathrm{mg} \mathrm{L}^{-1} ; \mathrm{DL}(\mathrm{As})=0.0012 \mathrm{mg} \mathrm{L}^{-1}$. (a) Results from March 2012 were not presented, because in this period the stream was at its dry phase, without flow. 
Biochemical oxygen demand $\left(\mathrm{BOD}_{5}\right)$ and chemical oxygen demand (COD), parameters that influence the oxygenation conditions of water bodies, reached very high values at the source of the stream $\left(\mathrm{BOD}_{5}\right.$ : 18.5-25.5 $\mathrm{mg} \mathrm{L}^{-1}$; COD: $60.8-193.7 \mathrm{mg} \mathrm{L}^{-1}$ ). According to INAG (2009), concentrations of $\mathrm{BOD}_{5}$ and COD higher than $5 \mathrm{mg} \mathrm{L}^{-1}$ and $20 \mathrm{mg} \mathrm{L}^{-1}$, respectively, compromise the essential conditions for the support of biological life, classifying the water as "Less than Good". These results support the above statement about the intensive processes of pollution that occur at this watercourse. In general, at site 2 , the amounts of both parameters decreased, being March 2012 the month when they were quantified at the lowest concentrations $\left(\mathrm{BOD}_{5}\right.$ $<$ detection limit (LD); COD: $29.9 \mathrm{mg} \mathrm{L}^{-1}$ ). Generally, similar temporal patterns were observed for the nutrients parameters ((total nitrogen (TN), total phosphorus TP)), with higher amounts at the source of the stream. Thus, the TN achieved very high concentrations ( $37.75 \mathrm{mg} \mathrm{L}^{-1}$ ) in June 2011, probably due to the increment of organic matter from the point pollution sources (wastewater discharges from wastewater treatment plants of the municipalities of Zambujeira and Vila Nova de Milfontes), as well as to the excess of biological activity, as reported by other authors (Korkança et al., 2017; Palma et al., 2014b). The highest concentrations of TP occurred in site 1 (stream source: $0.17-0.23 \mathrm{mg} \mathrm{L}^{-1}$ ). All these values lead to a status classification of this section of the Brejo of Cagarrão as "Less than Good" with respect to ecological conditions. These results suggest that the main focuses of pollution are near the source of the stream, and when during the drying phase, the main contamination processes are not transferred downstream. Further, the positive correlations observed between $\mathrm{BOD}_{5}$ and $\mathrm{TP}(R=0.77 ; p<0.05) ; \mathrm{BOD}_{5}$ and TN $(R=0.92 ; p<0.05) ; \mathrm{BOD}_{5}$ and $\mathrm{NH}_{4}-\mathrm{N}(R=0.79 ; p<0.05) ; \mathrm{BOD}_{5}$ and $\mathrm{NO}_{2}-\mathrm{N}(R=0.81 ; p<0.05)$ suggest the same sources of contamination, namely wastes from agriculture and livestock activities, as observed elsewhere for the Guadiana Basin (Palma et al., 2014b).

Concerning the trace elements, and since the normative for the classification of the ecological status of the water bodies (INAG, 2009) does not integrate them, nor the Directive for "good chemical status" (ECC, 2013), we followed the Portuguese legislation regarding water for multiple uses (Decreto-Lei ${ }^{\circ}$. 236/98, 1998). Iron concentrations in the water stream (site 1 and site 2 ) were very high, with values at site 1 ranging from 0.46 to $1.99 \mathrm{mg} \mathrm{L}^{-1}$ and at site 2 between 0.29 and $0.52 \mathrm{mg} \mathrm{L}^{-1}$, always surpassing the legal limit value of $0.1 \mathrm{mg} \mathrm{L}^{-1}$. As for $\mathrm{Mn}$, the concentrations found were lower than the limit value of $0.025 \mathrm{mg} \mathrm{L}^{-1}$ only at Site 2 (January and March 2012). The high concentrations for these trace elements were probably the result of diffuse pollution (predominantly from wastewater discharges), and not a result of the lithology of the basin. Several facts support this assumption: (i) the positive significant correlation observed between nutrients (that in the study resulted from undertreated or inefficiently treated wastewater discharges) and trace elements (see Table S1); (ii) the fact that the Mira Basin sediments are mainly constituted by clay and their amounts of organic matter range 0.7-2.0\% (Mil-Homens et al., 2014), factors that contribute to the adsorption of the trace elements to the sediments decreasing the processes of resuspension to the water column; and (iii) the fact that the primary trace elements detected in the sediments were $\mathrm{Cr}\left(73-104 \mu \mathrm{g} \mathrm{L}^{-1}\right)$, Ni (42-62 $\left.\mu \mathrm{g} \mathrm{L}^{-1}\right)$ and Co (16-29 $\mu \mathrm{g} \mathrm{L}^{-1}$ ) resulting, according to the authors, from the weathering of the basic rocks formations and doleritic veins existing in the formations of the volcano-sedimentary complex of the Odemira and Pomarão areas (Mil-Homens et al., 2014), elements that were not detect in the water column.

\subsection{Dynamic of pesticides at Brejo of Cagarrão stream}

In general, Brejo of Cagarrão stream exhibited moderate concentrations of the target pesticides. Although all samples had pesticides, only five (all herbicides), out of the 25 compounds analysed, were detected, namely, terbuthylazine (triazine), metolachlor (chloroacetanilide), bentazone, MCPA and mecoprop (acid compounds) (see Fig. 2). All five pesticides were detected in all samples. Mecoprop was the herbicide detected at lower concentrations (Site 1: 7.6-8.0 $\mathrm{ng} \mathrm{L}^{-1}$; Site 2: 2.1-7.1 $\mathrm{ng} \mathrm{L}^{-1}$ ), while bentazone and MCPA (usually formulated together) showed the largest maximum concentrations: up to $1769 \mathrm{ng} \mathrm{L^{-1 }}$ of bentazone in Site 1 in January 2012, and up to $580 \mathrm{ng} \mathrm{L}^{-1}$ of MCPA in Site 2 in June 2011. None of the pesticides quantified are included in the list of priority substances in the field of water policy (ECC, 2013), however two of them (bentazone and mecoprop) were considered to review for possible identification as priority substances or priority hazardous substances (Directive 2008/105/EC). Nonetheless, all but mecoprop surpassed the reference value of $100 \mathrm{ng} \mathrm{L}^{-1}$ set as maximum admissible concentration (MAC) for individual compounds in groundwater (ECC, 2006) and drinking water (ECC, 1998): terbuthylazine and metolachlor (usually formulated together for maize crop application) surpassed this limit in $71 \%$ and $42 \%$ of the samples, respectively, while bentazone and MCPA exceeded this value only once during the study. It may be worth noting that

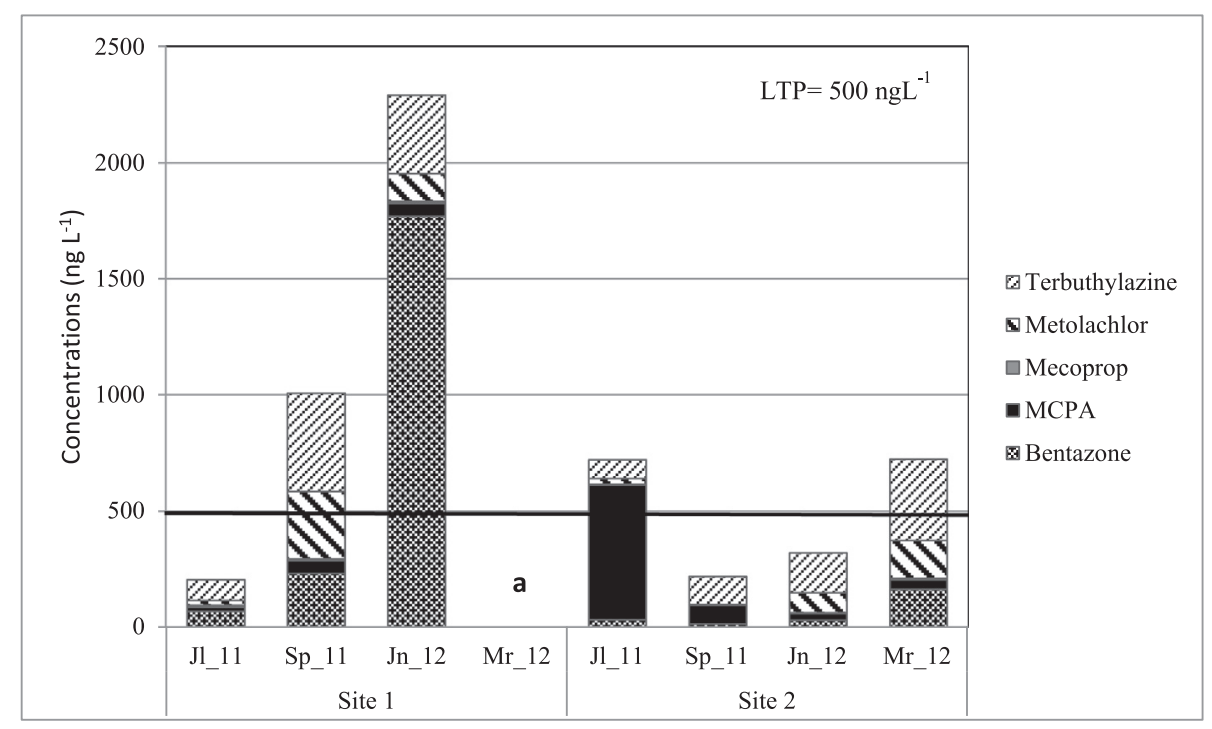

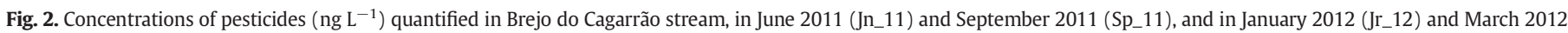
(Mr_12). (a. Site 1 at March 12, corresponding to the dry phase). 
terbuthylazine and metolachlor are included in the list of specific substances presenting a significant risk to the neighboring Spanish surface waters, due to their special toxicity, persistence and bioaccumulation, or the importance of their presence in the Spanish aquatic environment (Real Decreto $\left.n^{\circ} .817 / 2015,2015\right)$. The sample with the lowest value of the sum of pesticides ( $204 \mathrm{ng} \mathrm{L}^{-1}$ ) was collected at site 1 , in June 2011, while the sample exhibiting the largest overall concentration of the pesticides ( $2291 \mathrm{ng} \mathrm{L}^{-1}$ ), due mainly to the concentration achieved by bentazone ( $1769 \mathrm{ng} \mathrm{L}^{-1}$ ), was collected also from site 1 in January 2012. The reference value of $500 \mathrm{ng} \mathrm{L}^{-1}$, set as the MAC for the sum of pesticides (including metabolites and transformation products), in groundwater (ECC, 2006) and drinking water (ECC, 1998), was surpassed at the source of the stream in the samples from September 2011 and January 2012, and at the mouth of the stream, in the samples from June 2011 and March 2012. These results highlight the fact that, as far as pesticides are concerned, both sections of the stream present different and not correlated patterns of pollution. Contrarywise to what has been observed for the dynamics of the chemical parameters, and even though the pesticides detected are the same (probably because the crops around the two sections are similar, mainly maize crops), the source section may not influence the contamination patterns at the mouth of stream during the dry phase. Furthermore, the nonexistence of significant correlations among support chemical parameters and quantified pesticides supports this hypothesis (see Table S1).

\subsection{Ecotoxicological assessment}

All ecotoxicological tests reported fulfilled the validity requirements established by their respective guidelines.

The short-term bioassays used, with T. platyurus and D. magna, did not detect toxicity among the samples tested. The relative low sensitivity of the $D$. magna lethality bioassay to surface waters with low pesticide concentrations (lower than the EQS values, ECC, 2013) has already been reported in rivers and heavily modified water bodies (HMWB) by other authors (Ieromina et al., 2014; Palma et al., 2016). In contrast, previous results with the anostracan $T$. platyurus highlighted the sensitivity of the crustacean to detect low levels of pesticides in HMWB, being considered as good alternative to $D$. magna, when integrating primary consumers in toolboxes for acute ecotoxicity screening of surface waters contaminated by pesticides (Palma et al., 2016). The quantification only of pesticides belonging to herbicide classes (triazines, acids and chloroacetanilides) may justify the acute ecotoxicological results observed during the study, once the crustaceans are most sensitive to insecticides and fungicides (Palma et al., 2008; Bunzel et al., 2015).

The bioassay with $V$. fischeri (sublethal effect) detected toxicity after 30 min of exposure to the sample of January 2012 from the Site 1 (source section of the stream), with an $\mathrm{EC}_{20}(\% ; v / \mathrm{v})$ of 11.56; [11.19-11.91] (mean values and 95\% confidence interval; $n=2$ ). The results of the correlation matrix showed significant positive correlations between the bioluminiscence inhibition of the bacterial $V$. fisheri and the increment of the concentrations of $\operatorname{COD}(R=0.86 ; p<0.05)$, Fe $(R=0.92 ; p<$ $0.05)$, and bentazone $(R=0.80 ; p<0.05)$, suggesting that these three parameters are the main responsible for the toxicity observed. Accentuated bioluminescence inhibition with increasing Fe concentrations at water bodies has already been reported elsewhere (Palma et al., 2016).

The life-cycle assessment through the reproduction bioassay with $D$. magna was the most sensitive test, detecting toxicity at Site 1 in June 2011 (one-way ANOVA; $F_{4,45}=9.68 ; p=0.0001$ ), September 2011 (one-way ANOVA; F4,44 = 3.46; $p=0.01527$ ), January 2012 (one-way ANOVA; $F_{4,45}=6.61 ; p<0.0005$ ), and at Site 2 in January 2012 (one-way ANOVA; $\mathrm{F}_{4,45}=12.51 ; p<0.0001$ ) and in March 2012 (one-way ANOVA; $\mathrm{F}_{4,37}=10.62 ; p=0.0001$ ) (see Fig. 3 ). The responses observed at Site 1 were probably due to the high levels of the potentially toxic metals Fe, Mn and As, jointly with the presence of pesticides, namely terbuthylazine. The correlation with the presence of As and terbuthylazine and the decrease of the D. magna reproduction rate has already been reported in other studies (Palma et al., 2010; Palma et al., 2016).

Notwithstanding, in previous studies, it was possible to conclude that the increment of nutrients and organic descriptors may improve the reproductive performance of the crustacean and mask the toxic effect promoted by pesticides (Palma et al., 2016). In the present study, this effect did not occur, once the reproduction rate decreased significantly in the samples with the highest concentrations of COD and $\mathrm{BOD}_{5}$, probably because organic matter, above a given concentration, can also contribute to a toxic environment. In Site 2, the decrease of juveniles probably happened due to the presence of pesticides, which reached their highest concentrations in March 2012 ( $\left.723 \mathrm{ng} \mathrm{L}^{-1}\right)$. This result highlights the importance of pesticides in the ecotoxicological responses observed, once in March 2012, when the levels of other chemical parameters and potential toxic metals lowered, due to the dry phase of the stream, and to the levels of pesticides which remained high, the negative effects continued to be observed.

These results emphasize the importance of integrating longerexposure bioassays, with higher ecological relevance, to assess more thoroughly the ecotoxicity of surface water samples. These samples are, in general, matrices with lower ecotoxicity, more difficult to be detected by short-term exposition.

The results highlight that an ecotoxicological approach, with sensitive species, allow us to link the presence of chemical stressors with the negative effects observed in the ecosystem communities, condition required for the development of specific management actions in waters. Furthermore, the use of ecotoxicological tools can be very useful in the ecological risk assessment of surface waters where reference scenarios are difficult to be established, such as in temporary streams, once most of them occur intermittently due to the extreme climate conditions.

\subsection{Macroinvertebrates}

To evaluate the structure of the benthic communities at the studied sites, we sampled 1616 individuals belonging to 14 taxa (see Table 4). The dominant groups were Diptera (29.9\%) and Coleoptera (29.5\%), followed by Ephemeroptera (23.8\%), Heteroptera (6.7\%), Plecoptera (5.8\%) and Odonata (3.4\%). The group of Gastropoda represented only $0.4 \%$ of the total number of individuals, appearing punctually at Site 1 (June 2011) (see Fig. 4). As expected, in winter, it was impossible to find individuals from Gastropoda, due to the lower abundance of macrophytes, the primary habitat for this group, returning in the springsummer when habitat conditions are favourable (Trigal et al., 2007). During the study, the abundance was lower than the metrics benchmarks for small southern rivers of Portugal (27.00; INAG, 2009), which is an indicator of the existence of environmental stress conditions (Bio et al., 2011; Trigal et al., 2007). Several authors have reported that the increase in $\mathrm{NH}_{4}-\mathrm{N}$ concentration in aquatic ecosystems induces a decrease in the abundance of benthic invertebrates (Versteeg et al., 1999; Blanco and Bécares, 2010). In the present study the concentrations of $\mathrm{NH}_{4}$-N were elevated mainly in Site 1, which may justify the results observed. In the study, we only observed two of the reference taxa (Chironomidae and Elmidae) reported for temporary streams of South of Portugal with almost no slope $(0.7 \%)$ and high conductivity (>566 mS/cm) (Feio et al., 2009).

The benthic communities did not present an accentuated temporal and spatial variability, occurring a slight increment of the percentage of the principal taxa during the spring-summer, justified by the continuous flow conditions and by the food availability, which is generally greater in this period (Leitão et al., 2014). Moreover, the principal order presented at Site 1 was Diptera represented solely by the Chironomidae family, and at Site 2 was Ephemeroptera, represented by the Ephemerellidae, Ephemeridae and Oligoneuriidae families. Henceforth, and relatively to the tolerance to pollution, the Site 1 was dominated, in general, by resistant families, whose presence is correlated with low 


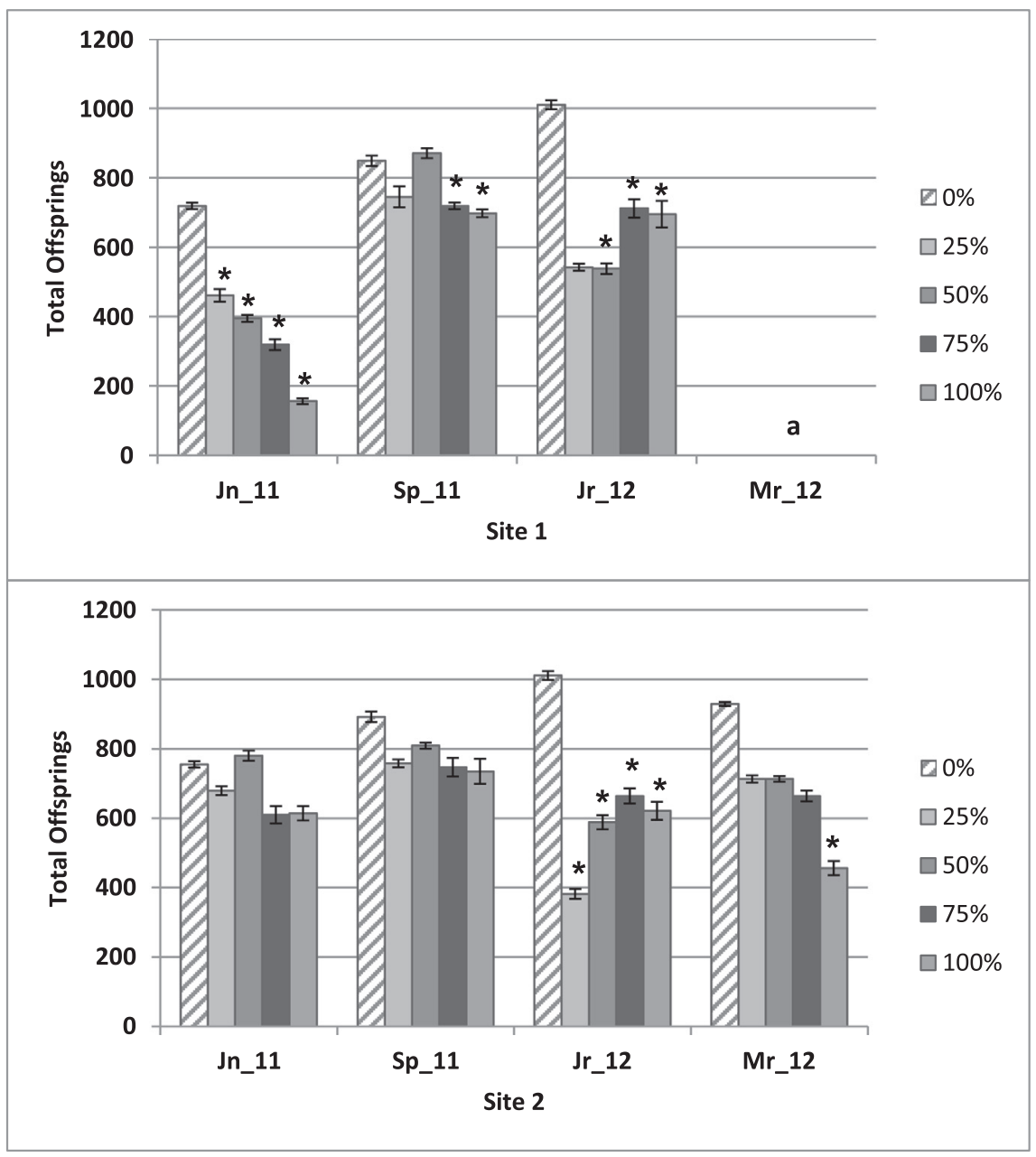

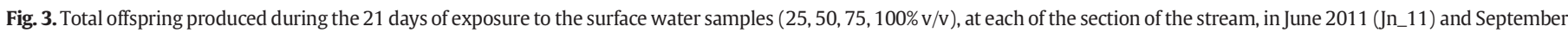

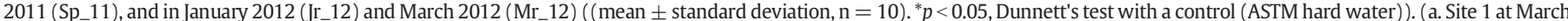
12 , corresponding to the dry phase).

concentrations of oxygen, nutrient enrichment and organic pollution (Bio et al., 2011). Contrariwise, Site 2 was dominated by less tolerant families, being, for example, the individuals of Ephemerellidae and Ephemeridae very sensitive to pesticides, with a SPEAR index (Species at Risk index) of 1 (SPEAR $=1$, specie at risk; SPEAR $=0$, specie at no risk; Liess and von der Ohe, 2005). The EPT index presented values above the reference, correlated with the Taxa of Ephemeroptera and Plecoptera, once the Trichoptera was not observed during the study. Trichoptera, among the three families, is the most sensitive to organic pollution, as well as, to hazardous substances like pesticides; most of the species belonging to this family present a SPEAR index for pesticides of 1 (Liess and von der Ohe, 2005). The macroinvertebrate diversity varied slightly between seasons/months, presenting values considered low in the range of normal index variation. Thus, at Site 1, the ShannonWiener index $(\mathrm{H})$ ranged between 1.80 (June 2011) and 2.03 (January 2012) and at Site 2 from 1.52 (January 2012) to 2.20 (September 2011) (see Table 4). This result supports the previous ones reporting the high organic pollution and the presence of pesticides in the stream, once that, in general, the high species richness is correlated with an adequate availability of habitats with food sources and niches to be occupied

Table 4

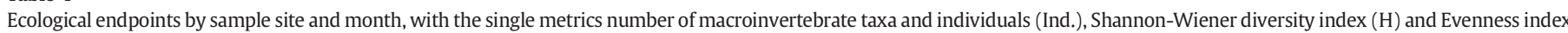
(E), the quality indices of Iberian Bio-Monitoring Working Party index (IBMWP), and the Iberian Average Score Per Taxon (IASPT-2), and the Ecological Quality Ratio (EQR).

\begin{tabular}{|c|c|c|c|c|c|c|c|c|c|c|c|}
\hline \multirow[t]{2}{*}{ Site } & \multirow[t]{2}{*}{ Month } & \multirow[t]{2}{*}{ Taxa } & \multirow[t]{2}{*}{ Ind. } & \multirow[t]{2}{*}{$\%$ EPT } & \multirow[t]{2}{*}{$\mathrm{H}$} & \multirow[t]{2}{*}{$\mathrm{E}$} & \multirow[t]{2}{*}{ IASPT-2 } & \multicolumn{2}{|c|}{ IBMWP } & \multicolumn{2}{|l|}{ EQR } \\
\hline & & & & & & & & Score & Class & Score & Class \\
\hline \multirow[t]{4}{*}{1} & Jn & 12 & 241 & 25.0 & 1.80 & 0.73 & 3.64 & 62 & II & 0.59 & III \\
\hline & Sp & 7 & 292 & 14.3 & 1.61 & 0.83 & 2.43 & 31 & IV & 0.43 & IV \\
\hline & $\mathrm{Jr}$ & 10 & 188 & 30.0 & 2.03 & 0.88 & 3.90 & 59 & III & 0.60 & III \\
\hline & $\mathrm{Mr}$ & (a) & & & & & & & & & \\
\hline \multirow[t]{4}{*}{2} & Jn & 9 & 185 & 33.3 & 1.92 & 0.87 & 3.33 & 48 & III & 0.54 & III \\
\hline & Sp & 11 & 173 & 45.5 & 2.20 & 0.92 & 4.18 & 68 & II & 0.66 & III \\
\hline & $\mathrm{Jr}$ & 6 & 269 & 16.7 & 1.52 & 0.85 & 2.67 & 28 & IV & 0.42 & IV \\
\hline & $\mathrm{Mr}$ & 10 & 262 & 40.0 & 1.94 & 0.84 & 3.80 & 58 & III & 0.62 & III \\
\hline
\end{tabular}

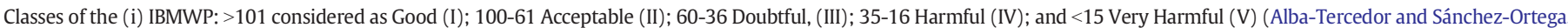

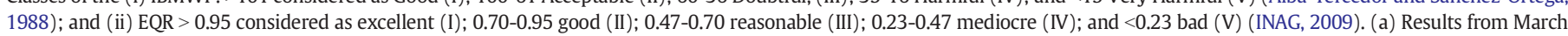
2012 were not presented, because in this period the stream was at its dry phase (without flow). 


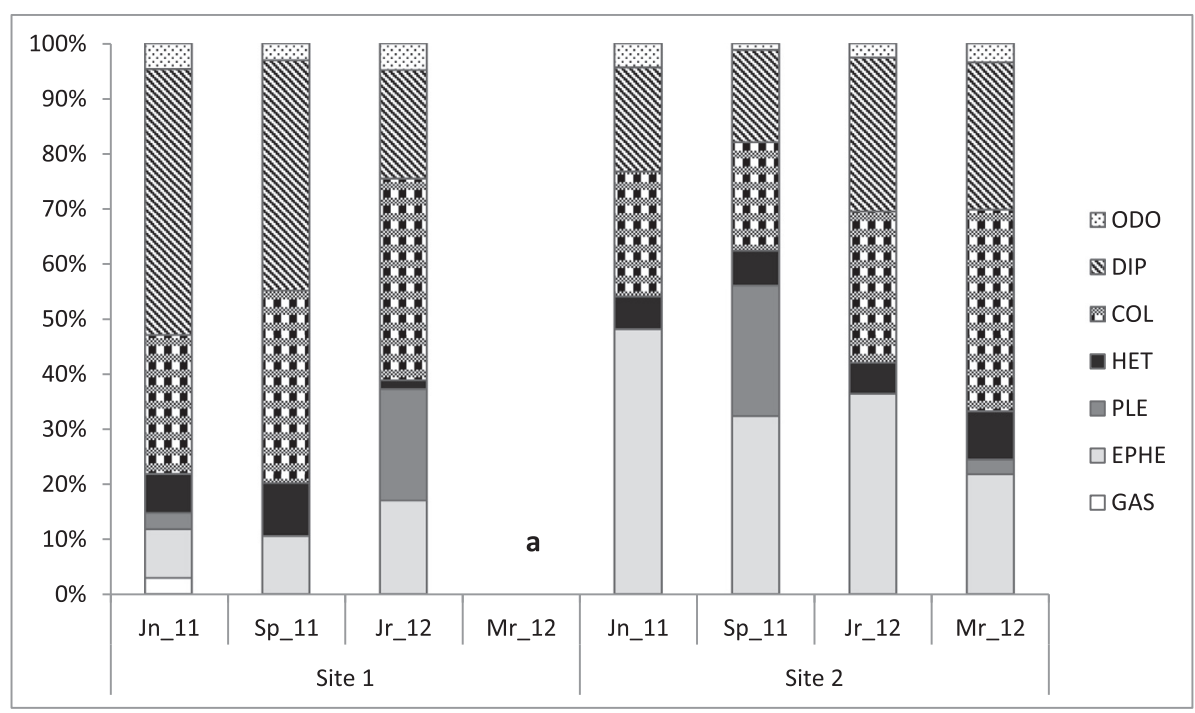

ODO: Odonata; DIP: Diptera; COL: Coleoptera; HET: Heteroptera; PLE: Plecoptera; EPHE:

Ephemeroptera; GAS: Gastropoda.

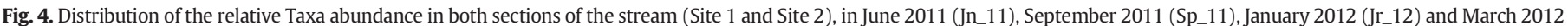

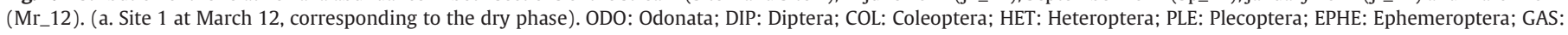
Gastropoda.

and without pollution, supporting the propagation and survival of the aquatic biota (Schäfer et al., 2016). In addition to the low diversity of the benthic organisms, their distribution was uniform for the existing taxonomic groups, since in general, the Evenness index ranged from 0.73 (Site 1 in June 2011) to 0.92 (Site 2 in September 2011). The correlation matrix of Evennes index showed negative correlations with nutrients, namely, TP $(R=-0.84 ; p<0.05)$, $\mathrm{KN}(R=-0.77 ; p<0.05)$ and $\mathrm{NH}_{4}{ }^{-}$ $\mathrm{N}(R=-0.78 ; p<0.05)$, and with the reproduction inhibition of D. magna $(R=-0.81 ; p<0.05)$. Liess and von der Ohe (2005) had already observed negative correlations between abundance of macroinvertebrates and $D$. magna toxicity, at areas strongly contaminated by pesticides.

According to the IBMWP index, a quality index more sensitive to organic pollution than to hazardous substances (García et al., 2014; von der Ohe and Goedkoop, 2013), the ecological status of the water body ranges from acceptable to harmful (Class II-IV; see Table 4). Medeiros et al. (2012), reported similar classifications of watercourses at the Mira estuary. As expected, the IBMWP index, showed strong positive correlations with abundance $(R=0.95 ; p<0.05)$, Shannon-Wiener index $(R=0.78$; $p<0.05$ ), and $\mathrm{EQR}$ (environmental quality ratio) $(R=0.85 ; p<0.05$ ), which denote the consistence between the indices used. The EQR index results of the normalization of the Southern Portuguese Index of Invertebrates, obtained through the sum of the weighting of the remaining indices. This index gives us complete and integrated information about the biotic macroinvertebrates communities, being more sensitive and complete that the IBMWP, and classifying the ecological status of the stream from reasonable to mediocre (class III-IV), during the study.

The Brejo of Cagarrão stream displayed a general gradient of worse to better water quality, from up (Site 1) to downstream (Site 2). This gradient was more marked in chemical support parameters and in pesticides than in ecotoxicological endpoints and biotic indices. This pattern was also observed in other Portuguese rivers and streams, such as Febros (Bio et al., 2011) and Odelouca (Silva, 2012), and in transitional waters, like in the Mira estuary (Leitão et al., 2014).

\subsection{Multivariate statistical analysis}

PCA allowed the identification of four main components (PCs) using the Kaiser criterion (Kaiser, 1960), which explains $88 \%$ of the total variance. PC1 explained $31 \%$ of the original data and was correlated principally with nutrients and trace elements. Therefore, $\mathrm{PC} 1$ is strongly positively associated with $\mathrm{TP}, \mathrm{KN}, \mathrm{NH}_{4}-\mathrm{N}, \mathrm{Mn}, \mathrm{As}$, abundance of taxa (S) and IBMP index; moderately positively related with $\mathrm{BOD}_{5}$, $\mathrm{H}$ diversity index and EQR index; and moderately negatively participated by metoalachlor and total number of individuals (N) (see Fig. 5a). PC2 explained $22 \%$ of the variance and was strongly negatively participated by $\mathrm{NO}_{3}-\mathrm{N}, \mathrm{NO}_{2}-\mathrm{N}$, and number of total individuals $(\mathrm{N})$, and positively correlated with EPT, $\mathrm{H}$ and E metrics. PC3 explained 20\% of the total variance and was mainly participated by temperature (negative side), $\mathrm{COD}$, chloride $(\mathrm{Cl})$, bentazone and luminescence inhibition (positive side) (following the Liu et al. (2003) classification: strong correlation (factor score $>0.75$ ); moderate correlation (factor score 0.75-0.5). This PC3 was the only one that correlated the presence of pesticides with ecotoxicological endpoints.

The score of the water samples more influenced by the parameters that explained the two first PCs are represented in Fig. 5b. The samples with worst quality and lower biotic indices were from the source of the stream (Site 1), located at the positive quadrant of PC1 and at the negative quadrant of PC2. Contrarywise, samples collected at Site 2, from March and January, were located at the positive quadrant of PC2, indicating that they were less influenced by COD, nutrients and metolachlor, and on the negative quadrant of PC1 (less influenced by nutrients and $\mathrm{BOD}_{5}$ ), which constituted the samples with the highest quality and higher metric indexes.

PCA confirmed the previous results, namely, that the pesticides presented a lower influence in the water quality of the stream than nutrients and potential toxic metals, as well as that the samples with worst quality were from the source of the stream. Further, PCA results also highlight that the variability of metric indices was more influenced by nutrients and potentially toxic metals, and that the ecotoxicological effects were more correlated with pesticides.

\section{Conclusions}

Temporary streams are dominant freshwater systems in the Mediterranean region, and their number is expected to increase, due to climate change and to the increasing inappropriate use of freshwater resources. So, it is important/ urgent to obtain more information about their hydrological, chemical, and biological behaviour. However, 

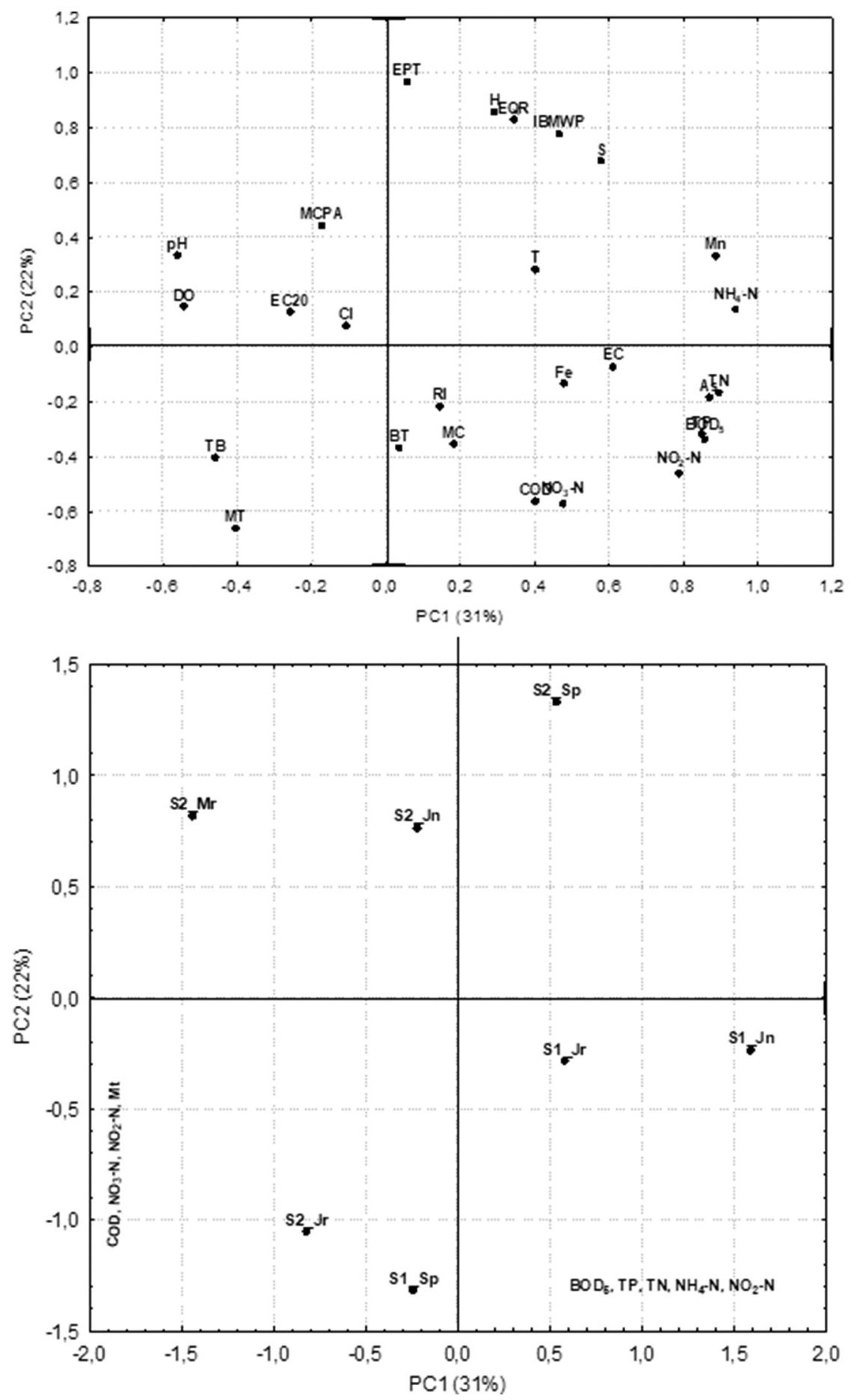

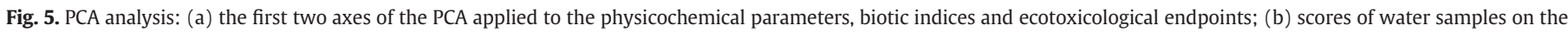

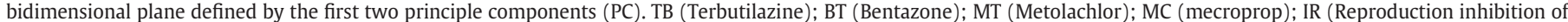

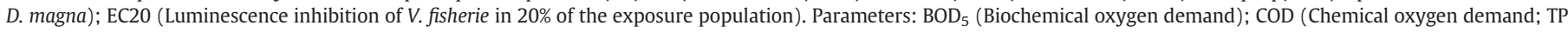

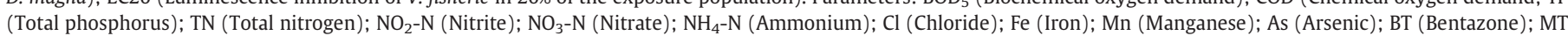

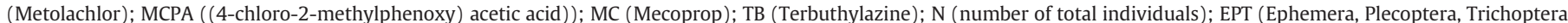

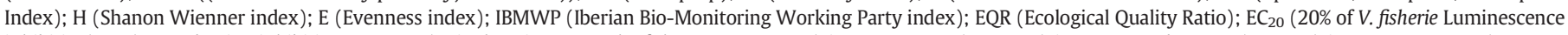

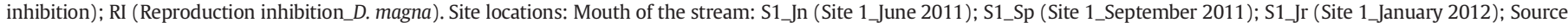
of the stream: S2_Jn (Site 2_June 2011); S2_Sp (Site 2_September 2011); S2_Jr (Site 2_January 2012); S2_Mr (Site 2_March 2012).

chemical, and biological assessment of this type of surface water is not an easy task. The unknown and strong variability of hydrological regimes and flows, very dependent on climate conditions, limits the development of sampling plans, complicates the determination of reference sites, and of the best biological parameters for the quality assessment of a specific watercourse. Hence, it is important to increase the number of research studies and results in temporary rivers/streams to decrease the gap of knowledge in this type of systems and help in choosing the best indicators that can be used for their management and restoration.

The results obtained for the assessment of the ecological status of the temporary stream of Brejo of Cagarrão provide evidence of severely 
degraded conditions, mainly at the source of the stream, compromising the biodiversity and the respective abundance of species, and classifying this water line with an ecological status lower that good. Furthermore, these results deserve considerable concern, once this stream is in the Southwest Alentejo and Vicentine Coast Natural Park, near Brejo Largo Beach, and may also raise public health issues.

The chemical contamination was principally due to pollution processes located near the source of the stream (intensive agriculture, livestock activities and untreated or insufficient treatment of wastewaters), once the results showed that when the inflection (dry phase) occurs the mouth of the stream presents a better quality. The nutrients and organic matter were the main parameters responsible for the variability of the water quality at the stream.

In general, the multi-metric indices used classified the ecological status of the stream as reasonable to mediocre, being more sensitive to nutrients and organic matter. In the present study, only the sub-lethal ecotoxicological endpoints showed sensitivity to the observed contamination, indicating that, at least during some periods of time, some populations may have been affected and biodiversity compromised. This group of tools was more sensitive to pesticides, than to nutrients or organic matter, although the substances detected belonged only to classes of herbicides and their concentrations were, in general, considered low.

The current results support the complementary use of macroinvertebrate indices and ecotoxicological sub-lethal endpoints in the assessment of ecological status of temporary streams, once they exhibit differential sensitivities, depending on the type of pollutant.

The results highlighted the linearity of the responses among the two groups of biological methodologies. Nevertheless, further studies including more sampling campaigns, the assessment of sediment matrices at the dry phase, and the use of a higher number of bioindicators would be needed, to generalize our findings and to establish thresholds easy to apply and understand in programs of management and restoration of this type of ecosystem.

Supplementary data to this article can be found online at https://doi. org/10.1016/j.scitotenv.2018.03.281.

\section{Acknowledgments}

The present research is co-funded by the European Union through the European Regional Development Fund, included in the COMPETE 2020 (Operational Program Competitiveness and Internationalization) through the ICT project (UID/GEO/04683/2013) with the reference POCI-01-0145-FEDER-007690 and also through the ALOP (ALT20-030145-FEDER-000004), by the European Union through the EU FP7 project SOLUTIONS (603437), and by the Government of Catalonia (Consolidated Research Groups 2017 SGR 1404 - Water and Soil Quality Unit). It reflects only the author's views. The Community is not liable for any use that may be made of the information contained therein. Merck is acknowledged for the gift of LC columns.

\section{References}

Acuña, V., Datry, T., Marshall, J., Barceló, D., Dahm, C.N., Ginebreda, A., McGregor, G. Sabater, S., Tockner, K., Palmer, M.A., 2014. Why should we care about temporary waterways? Science $343,1080-1081$.

Alba-Tercedor, J., Sánchez-Ortega, A., 1988. Un método rápido y simple para evaluar la calidad biológica de las aguas corrientes basado en el de Hellawell (1978). Limnetica 4, 51-56 (in Spanish)

APHA (America Public Health Association), 1998. Standard Methods for the Examination of Water and Wastewater. New York.

Araújo, R.S., Alves, M.G., Condesso de Melo, M.T., Chrispim, Z.M.P., Mendes, M.P., Silva Júnior, G.C., 2014. Water resource management: a comparative evaluation of Brazil, Rio de Janeiro, the European Union, and Portugal. Sci. Total Environ. 511, 815-828.

Arenas-Sánchez, A., Rico, A., Vighi, M., 2016. Effects of water scarcity and chemical pollution in aquatic ecosystems: state of the art Sci. Total Environ. 572, 390-403.

ARHAlentejo (Administração da Região Hidrográfica do Alentejo I.P.), 2011. Plano de gestão das bacias hidrográficas integradas nas regiões hidrográficas 6 e 7: Região Hidrográfica 7. Ministério do Ambiente e do Ordenamento do Território. Lisboa (in Portuguese).
ARHAlentejo (Administração da Região Hidrográfica do Alentejo I.P.), 2012. Plano de gestão das bacias hidrográficas integradas nas regiões hidrográficas 6 e 7: Região Hidrográfica 7. Ministério do Ambiente e do Ordenamento do Território. Lisboa (in Portuguese).

Artigas, J., Arts, G., Babut, M., Caracciolo, A.B., Charles, S., Chaumot, A., Combourieu, B., Dahllöf, I., Despréaux, D., Ferrari, B., Fribergi, N., Garric, J., Geffard, O., GourlayFrancé, C., Hein, M., Hjorth, M., Krauss, M., De Lange, H.J., Lahr, J., Lehtonen, K.K., Lettieri, T., Liess, M., Lofts, S., Mayer, P., Morin, S., Paschke, A., Svendsen, C., Usseglio-Polatera, P., van den Brink, N., Vindimian, E., Williams, R., 2012. Towards a renewed research agenda in ecotoxicology. Environ. Pollut. 160, 201-206.

ASTM, 1998. Standard practice for conducting toxicity tests with fishes, macroinvertebrates and amphibians. Annual Book of ASTM Standards, E729-90. Philadelphia, pp. 271-296.

Baird, D.J., Barber, I., Bradley, M., Calow, P., Soares, A.M.V.M., 1989. The Daphnia bioassay: a critique. Hydrobiologia 188-189, 403-406.

Beketov, M.A., Liess, M., 2012. Ecotoxicology and macroecology and time for integration. Environ. Pollut. 162, 247-254.

Bio, A., Vieira, N., Costa, M.J., Valente, A., 2011. Assessment of habitat and water quality of the Portuguese Febros River and one of its tributaries. Limnetica 30 (1), 103-116.

Blanco, S., Bécares, E., 2010. Are biotic indices sensitive to river toxicants? A comparison of metrics based on diatoms and macro-invertebrates. Chemosphere 79, 18-25.

Bonada, N., Doledec, S., Statzner, B., 2007. Taxonomic and biological trait differences of stream macroinvertebrate communities between Mediterranean and temperate regions: implications for future climatic scenarios. Glob. Chang. Biol. 13 (8), 1658-1671.

Bunzel, K., Schäfer, R.B., Thrän, D., Kattwinkele, M., 2015. Pesticide runoff from energy crops: a threat to aquatic invertebrates? Sci. Total Environ. 537, 187-196.

Calhoun, A.J.K., Mushet, D.M., Bell, K.P., Boixd, D., Fitzsimons, J.A., Isselin-Nondedeu, F., 2017. Temporary wetlands: challenges and solutions to conserving a 'disappearing' ecosystem. Biol. Conserv. 211, 3-11.

Clements, W.H., Rohr, J.R., 2009. Community responses to contaminants: using basic ecological principles to predict ecotoxicological effects. Environ. Toxicol. Chem. 28, $1789-1800$

Colin, N., Porte, C., Fernandes, D., Barata, C., Padrós, F., Carrassón, M., Monroy, M., CanoRocabayera, O., de Sostoa, A., Piña, B., Maceda-Veiga, A., 2016. Ecological relevance of biomarkers in monitoring studies of macro-invertebrates and fish in Mediterranean rivers. Sci. Total Environ. 540, 307-323.

Cottarelli, V., Aygen, C., Mura, G., 2010. Fairy shrimps from Asiatic Turkey: redescription of Chirocephalus tauricus Pesta, 1921 and descriptions of Hirocephalus algidus sp. nov. and Chirocephalus brteki sp. nov. (Crustacea, Branchiopoda, Anostraca). Zootaxa 2528, 29-52.

Damásio, J., Barata, C., Munné, A., Ginebreda, A., Guasch, H., Sabater, S., et al., 2007. Comparing the response of biochemical indicators (biomarkers) and biological indices to diagnose the ecological impact of an oil spillage in a Mediterranean river (NE Catalunya, Spain). Chemosphere 66 (7), 1206-1216

Decreto Regulamentar n. ${ }^{\circ}$ 26/95 - Diário da República n. ${ }^{\circ}$ 219/1995, Série I-B. Ministério do Ambiente e Recursos Naturais. Lisboa.

Decreto-Lei n² 236/98, de 1 Agosto, 1998. Diário da república no. 176/98-I série A. Ministério do Ambiente. Lisboa.

ECC (European Community Comission), 1998. Comission Directive 98/83/EEC of 3 November. Quality of water intended for human consumption. Off. J. Eur. Communities, L330/32 0032-0054.

ECC (European Community Commission), 2000. Common Implementation Strategy for the Water Framework Directive (2000/60/EC). Guidance Document No. 27. Technical Guidance For Deriving Environmental Quality Standards. Technical Report - 2011 - 055.

ECC (European Community Commission), 2006. Decision 2006/118/EC on the protection of groundwater against pollution and deterioration. Off. J. Eur. Communities 19-31 L $372 / 19$.

ECC (European Community Commission), 2013. Decision 2013/39/EC on environmental quality standards in the field of water policy. Off. J. Eur. Communities 1-17 L 226/1.

Feio, M.J., Norris, R.H., Graça, M.A.S., Nichols, S., 2009. Water quality assessment of Portuguese streams: regional or national predictive models? Ecol. Indic. 9, 791-806.

Finney, D.J., 1971. Probit Analysis. Cambridge University Press, Cambridge, DC.

Gallart, F., Prat, N., Garcia-Roger, E.M., Latrón, J., Rieradevall, M., Llorens, P., Barberá, G.G., Brito, D., de Girolamo, A.M., Lo Porto, A., Buffagni, A., Erba, S., Neves, R., Nikolaidis, N.P., Perrin, J.L., Querner, E.P., Quiñonero, J.M., Tournoud, M.G., Tzoraki, O., Skoulikidis, N., Gómez, R., Sánchez-Montoya, M.M., Froebrich, J., 2012. A novel approach to analyzing the regimes of temporary streams inrelation to their controls on the composition and structure of aquatic biota. Hydrol. Earth Syst. Sci. 16, 3165-3182.

Gallart, F., Llorens, P., Latron, J., Cid, N., Rieradevall, M., Prat, N., 2016. Validating alternative methodologies to estimate the regime of temporary rivers when flow data are unavailable. Sci. Total Environ. 565, 1001-1010.

García, L., Pardo, I., Delgado, C., 2014. Macroinvertebrate indicators of ecological status in Mediterranean temporary stream types of the Balearic Islands. Ecol. Indic. 45, 650-663.

Harvey, R., Lye, L., Khan, A., Paterson, R., 2011. The influence of air temperature on water temperature and the concentration of dissolved oxygen in new found land rivers. Canadian Water Resources Journal 36 (2), 171-192.

Ieromina, O., Peijnenburg, W.J.G.M., de Snoo, G.R., Vijver, M.G., 2014. Population responses of Daphnia magna, Chydorus sphaericus and Asellus aquaticus in pesticide contaminated ditches around bulb fields. Environ. Pollut. 192, 196-203.

INAG (Portuguese Water Institute), 2008. Manual para a avaliação biológica da qualidade da água em sistemas fluviais segundo a Directiva Quadro da Água - Protocolo de amostragem e análise para os macroinvertebrados bentónicos. Ministério do Ambiente, do Ordenamento do Território e do Desenvolvimento Regional. Instituto da Água, Lisboa (in Portuguese). 
INAG (Portuguese Water Institute), 2009. Critérios para a classificação do estado das massas de água superficiais - rios e albufeiras. Ministério do Ambiente, do Ordenamento do Território e do Desenvolvimento Regional. Instituto da Água, Lisboa (in Portuguese).

ISO 11348-2, 1998. Determination of Inhibitory Effect of Water Samples on the Light Emission of Vibrio Fischeri (Luminescent Bacteria Test). Part 2: Method Using Liquid-dried Bacteria. International Organization for Standardisation, Geneve, Switzerland.

ISO 6341, 1996. Water Quality - Determination of the Inhibition of the Mobility of Daphnia magna Straus (Cladocera, Crustacea) - Acute Toxicity Test. International Organization for Standardisation, Geneve, Switzerland.

Kaiser, H.F., 1960. The application of electronic computers to factor analysis. Educ. Psychol. Meas. 20, 141-151. https://doi.org/10.1177/001316446002000116.

Korkança, S.Y., Kayıkçı, S., Korkanç, M., 2017. Evaluation of spatial and temporal water quality in the Akkaya dam watershed (Nigde, Turkey) and management implications. J. Afr. Earth Sci. 129, 481-491.

Leitão, F., Hughes, S.J., Máximo, I., Atanasova, N., Furtado, A., Chícharo, L., 2014. Habitat oriented sampling of macroinvertebrates affects the determination of ecological status in temporary Mediterranean river systems. River Res. Appl. 30, 1233-1247.

Liess, M., von der Ohe, P.C., 2005. Analyzing effects of pesticides on invertebrate communities in streams. Environ. Toxicol. Chem. 24 (4), 954-965.

Liu, C.W., Lin, K.H., Kuo, Y.M., 2003. Application of factor analysis in the assessment of groundwater quality in a Blackfoot disease area in Taiwan. Sci. Total Environ. 313, 77-89.

Medeiros, J.P., Chaves, M.L., Silva, G., Azeda, C., Costa, J.L., Marques, J.C., Costa, M.J., Chainho, P., 2012. Benthic condition in low salinity areas of the Mira estuary (Portugal): lessons learnt from freshwater and marine assessment tools. Ecol. Indic. 19, 79-88.

Mil-Homens, M., Vale, C., Raimundo, J., Pereira, P., Brito, P., Caetano, M., 2014. Major factors influencing the elemental composition of surface estuarine sediments: the case of 15 estuaries in Portugal. Mar. Pollut. Bull. 84, 135-146.

Munné, A., Prat, N., 2009. Use of macroinvertebrate-based multimetric indices for water quality evalution in Spanish Mediterranean rivers: an intercalibration approach with the IBMWP index. Hydrobiologia 628, 203-225.

Muñoz, I., Sabater, S., Barata, C., 2012. Evaluating ecological integrity in multi-stressed rivers: from the currently used biotic indices to newly developed approaches using biofilms and invertebrates. In: Guash, H., Ginebrada, A., Geiszener, A. (Eds.), Emerging and Priority Pollutants in Rivers. The Handbook of Environmental Chemistry Series. Springer, Berlin Heidelberg, pp. 219-241.

Naiman, R.J., Latterell, J.J., Pettit, N.E., Olden, J.D., 2008. Flow variability and the biophysical vitality of river systems. Compt. Rendus Geosci. 340, 629-643.

Nikolaidis, N.P., Demetropoulou, L., Froebrich, J., Jacobs, C., Gallart, F., Prat, N., Lo Porto, A., Campana, C., Papadoulakis, V., Skoulikidis, N., Davy, T., Bidoglio, G., Bouraoui, F. Kirkby, M., Tournoud, M.G., Polesello, S., Barberá, G.G., Cooper, D., Gomez, R., Sánchez-Montoya, M.M., Latron, J., De Girolamo, A.M., Perrin, J.L., 2013. Towards sustainable management of Mediterranean river basins: policy recommendations on management aspects of temporary streams. Water Policy 15, 830-849.

OCDE (Organization for Economic Cooperation and Development), 1998. OCDE 211, Daphnia magna Reproduction Test. OCDE, Paris.

von der Ohe, P.C., Goedkoop, W., 2013. Distinguishing the effects of habitat degradation and pesticide stress on benthic invertebrates using stressor-specific metrics. Sci. Total Environ. 444, 480-490.

Palma, P., Palma, V.L., Fernandes, R.M., Soares, A.M.V.M., Barbosa, I.R., 2008. Acute toxicity of atrazine, endosulfan sulphate and chlorpyrifos to Vibrio fischeri, Thamnocephalus platyurus and Daphnia magna, relative to their concentrations in surface waters from the Alentejo region of Portugal. Bull. Environ. Contam. Toxicol. 81, 485-489.

Palma, P., Alvarenga, P., Palma, V., Matos, C., Fernandes, R.M., Soares, A.M.V.M., Barbosa, I.R., 2010. Evaluation of surface water quality using an ecotoxicological approach: a case study of the Alqueva Reservoir (Portugal). Environ. Sci. Pollut. Res. 17, 703-716.

Palma, P., Köck-Schulmeyer, M., Alvarenga, P., Ledo, L., Barbosa, I.R., López de Alda, M., Barceló, D., 2014a. Risk assessment of pesticides detected in surface water of the Alqueva reservoir (Guadiana basin, southern of Portugal). Sci. Total Environ. 488-489, 208-219.

Palma, P., Ledo, L., Soares, S., Barbosa, I.R., Alvarenga, P., 2014b. Spatial and temporal variability of the water and sediments quality in the Alqueva reservoir (Guadiana Basin; southern Portugal). Sci. Total Environ. 470-471, 780-790.
Palma, P., Ledo, L., Alvarenga, P., 2016. Ecotoxicological endpoints, are they useful tools to support risk management strategies in strongly modified water bodies? Sci. Total Environ. 541, 119-129.

Persoone, G., 1999. THAMNOTOXKIT FTM - Crustacean Toxicity Screening Test for Freshwater. Standard Operational Procedure. Belgium.

Petrovic, M., Ginebreda, A., Acuña, V., Batalla, R.J., Elosegi, A., Guasch, H., de Alda, M.L., Marcé, R., Muñoz, I., Navarro-Ortega, A., 2011. Combined scenarios of chemical and ecological quality under water scarcity in Mediterranean rivers. Trac Trends Analytical Chemistry 30 (8), 1269-1278.

Poff, N.L., Allan, J.D., Bain, M.B., Karr, J.R., Prestegaard, K.L., Richter, B.D., et al., 1997. The natural flow regime. Bioscience 47, 769-784.

Real Decreto ${ }^{\circ} 817 / 2015$, de 11 de septiembre, 2015. Boletín oficial del Estado no. 219/ 2015 - Sec I. Criterios de seguimiento y evaluación del estado de las aguas superficiales y las normas de calidad ambiental. Ministerio de Agricultura Alimentación y Medio Ambiente.

Reyjol, Y., Argillier, C., Wendy, Bonne, Borja, A., Buijse, A.D., Cardoso, A.C., Daufresne, M. Kernanf, M., Ferreira, M.T., Poikane, S., Prat, N., Solheim, A.L., Stroffek, S., UsseglioPolatera, P., Villeneuve, B., van de Bund, W., 2014. Assessing the ecological status in the context of the European Water Framework Directive: where do we go now? Sci. Total Environ. 497-498, 332-344.

Sánchez-Montoya, M.M., Vidal-Abarca, M.R., Puntí, T., Poquet, J.M., Prat, N., Rieradevall, M., Alba-Tercedor, J., Zamora-Muñoz, C., Toro, M., Robles, S., Álvarez, M., Suárez, M.L., 2009. Defining criteria to select reference sites in Mediterranean streams. Hydrobiologia 619, 39-54.

Schäfer, R., Uhn, B., Malaj, E., Onig, A., Gergs, R., 2016. Contribution of organic toxicants to multiple stress in river ecosystems. Freshw. Biol. 61, 2116-2128.

Schinegger, R., Trautwein, C., Melcher, A., Schumutz, S., 2012. Multiple human pressures and their spatial patterns in European running waters. Water and Environment Journal 26, 261-273.

Silva, M.T.F.C., 2012. Macroinvertebrados como bioindicadores da qualidade da água em rios do Sul de Portugal: caso de estudo na Bacia Hidrográfica da Ribeira de Odelouca. Tese de Mestrado em Ecologia e Gestão Ambiental. Faculdade de Ciências, Universidade de Lisboa (in portuguese).

Simeonov, V., Stratis, J.A., Samara, C., Zachariadis, G., Voutsa, D., Anthemidis, A., et al., 2003. Assessment of surface water quality in Northern Greece. Water Res. 37 4119-4124.

Skoulikidis, Nikolaos T., Sabater, Sergi, Datry, Thibault, Morais, Manuela M., Buffagni, Andrea, Dörflinger, Gerald, Zogaris, Stamatis, Sánchez-Montoya, Maria del Mar Bonada, Nuria, Kalogianni, Eleni, Rosado, Joana, Vardakas, Leonidas, De Girolamo, Anna Maria, Tockner, Klement, 2017. Non-perennial Mediterranean rivers in Europe: status, pressures, and challenges for research and management. Sci. Total Environ. 577, 1-18

Sokal, R.R., Rohlf, F.J., 1995. Biometry: The Principles and Practice of Statistics in Biological Research. 3rd Edition. W.H. Freeman and Co., New York.

Stevenson, R.J., Sabater, S., 2010. Understanding effects of global change on river ecosystems: science to support policy in a changing world. Hydrobiologia 657, 3-18.

Trigal, C., Garcia-Criado, F., Alaez, C.F., 2007. Macroinvertebrate communities of mediterranean ponds (North Iberian Plateau): importance of natural and human-induced variability. Freshw. Biol. 52, 2042-2055.

Turner, R.K., Daily, G.C., 2008. The ecosystem services framework and natural capital conservation environmental and resource economics. Environ. Resour. Econ. 39, 25-35.

Van den Broeck, M., Waterkeyn, A., Rhazi, L., Grillas, P., Brendonck, L., 2015. Assessing the ecological integrity of endorheic wetlands, with focus on Mediterranean temporary ponds. Ecol. Indic. 54, 1-11.

Versteeg, D.J., Belanger, S.E., Carr, G.J., 1999. Understanding single-species and model ecosystem sensitivity: data-based comparison. Environ. Toxicol. Chem. 8 (6) 1329-1346.

Wunderlin, D.A., Díaz, M.P., Amé, M.V., Pesce, S.F., Hued, A.C., Bistoni, M.A., 2001. Pattern recognition techniques for the evaluation of spatial and temporal variations in water quality. A case study: Suquía River Basin (Córdoba-Argentina). Water Res. 35 (12), 2881-2894.

Zar, J.H., 1996. Biostatistical Analysis. Prentice-Hall International, Englewood Cliff, USA, DC. 